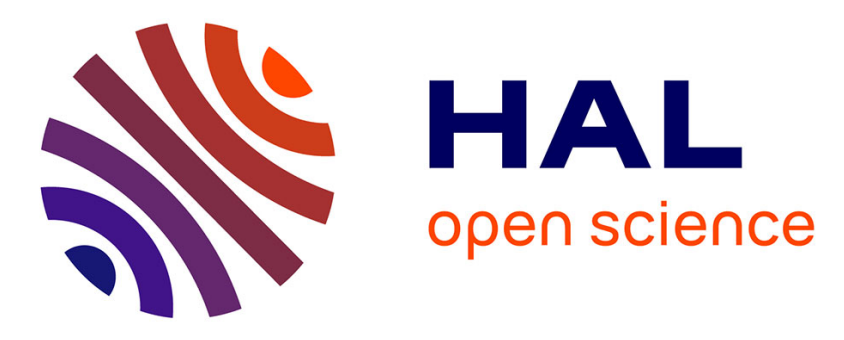

\title{
Bacterial diversity in typical abandoned multi-contaminated nonferrous metal(loid) tailings during natural attenuation
}

Jian-Li Liu, Jun Yao, Fei Wang, Ning Min, Ji-Hai Gu, Zi-Fu Li, Geoffrey Sunahara, Robert Duran, Tatjana Solevic-Knudsen, Karen Hudson-Edwards, et al.

\section{To cite this version:}

Jian-Li Liu, Jun Yao, Fei Wang, Ning Min, Ji-Hai Gu, et al.. Bacterial diversity in typical abandoned multi-contaminated nonferrous metal(loid) tailings during natural attenuation. Environmental Pollution, 2019, 247, pp.98-107. 10.1016/j.envpol.2018.12.045 . hal-01999642

\section{HAL Id: hal-01999642 https://hal.science/hal-01999642}

Submitted on 27 Nov 2020

HAL is a multi-disciplinary open access archive for the deposit and dissemination of scientific research documents, whether they are published or not. The documents may come from teaching and research institutions in France or abroad, or from public or private research centers.
L'archive ouverte pluridisciplinaire HAL, est destinée au dépôt et à la diffusion de documents scientifiques de niveau recherche, publiés ou non, émanant des établissements d'enseignement et de recherche français ou étrangers, des laboratoires publics ou privés. 


\section{ORE Open Research Exeter}

\section{TITLE}

Bacterial diversity in typical abandoned multi-contaminated nonferrous metal(loid) tailings during natural attenuation

\section{AUTHORS}

Liu, J-L; Yao, J; Wang, F; et al.

\section{JOURNAL}

Environmental Pollution

\section{DEPOSITED IN ORE}

07 February 2019

This version available at

http://hdl.handle.net/10871/35795 


\title{
Bacterial diversity in typical abandoned multi-contaminated nonferrous
}

\section{metal(loid) tailings during natural attenuation}

\author{
Jian-li Liu a , Jun Yao ${ }^{\text {* }}$, Fei Wang a , Ning Min ${ }^{\text {b }}$, Ji-hai Gu ${ }^{\text {b }}$, Zi-fu Li ${ }^{\text {***, }}$, \\ Geoffrey Sunahara ${ }^{b, c}$, Robert Duran b,d, Tatjana Solevic Knudsen ${ }^{\mathrm{e}}$, \\ Karen A. Hudson-Edwards ${ }^{g}$ and Lena Alakangas ${ }^{h}$
}

a School of Energy and Environment Engineering, University of Science and Technology Beijing, Beijing 100083, China

${ }^{b}$ School of Water Resource and Environment Engineering, China University of Geosciences (Beijing) 100083, China

c Department of Natural Resource Sciences, McGill University, Montreal, Quebec, H9X3V9, Canada

${ }^{\mathrm{d}}$ Equipe Environnement et Microbiologie, MELODY group, Université de Pau et des Pays de l'Adour, E2S-UPPA, IPREM UMR CNRS 5254, BP 1155, 64013 Pau Cedex, France

${ }^{\mathrm{e}}$ Institute of Chemistry, Technology and Metallurgy, University of Belgrade, Njegoseva 12, PO Box 473, 11001 Belgrade, Serbia

f Department of Applied Chemistry, Szent István University, Villányi út 35-43, 1118 Budapest, Hungary

g Environment \& Sustainability Institute and Camborne School of Mines, University of Exeter, Penryn, Cornwall TR10 9DF, UK

${ }^{\mathrm{h}}$ Lule University of Technology, -971 87 Lule1, Sweden

\section{Submitted to: Environmental Pollution}

Word count: 4316 (excluding Abstract, References and Figure and table captions)

Figures: 6

Tables: $\quad 3$

* Corresponding Author. School of Water Resource and Environment Engineering, China University of Geosciences (Beijing), 29 Xueyuan Road, Haidian District, 100083 Beijing, China, E-mail: yaojun@cugb.edu.cn (J. Yao), Tel: +86-10-82321958

** Corresponding Author. School of Energy and Environment Engineering, University of Science and Technology Beijing, 30 Xueyuan Road, Haidian District,100083 Beijing, China, E-mail: zifulee@aliyun.com (Z.F. Li), Tel: +86-10-62334378 


\section{Abstract}

Abandoned nonferrous metal(loid) tailings sites are anthropogenic, and represent unique and extreme ecological niches for microbial communities. Tailings contain elevated and toxic content of metal(loid)s that had negative effects on local human health and regional ecosystems. Microbial communities in these typical tailings undergoing natural attenuation are often very poorly examined. The diversity and inferred functions of bacterial communities were examined at seven nonferrous metal(loid) tailings sites in Guangxi (China), which were abandoned between 3 and 31 years ago. The acidity of the tailings sites rose over 31 years of site inactivity. Desulfurivibrio, which were always coupled with sulfur/sulfide oxidation to dissimilate the reduction of nitrate/nitrite, were specific in tailings with 3 years abandonment. However, genus beneficial to plant growth (Rhizobium), and iron/sulfuroxidizing bacteria and metal(loid)-related genera (Acidiferrobacter and Acidithiobacillus) were specific within tailings abandoned for 23 years or more. The increased abundance of acid-generating iron/sulfur-oxidizing and metal(loid)-related bacteria and specific bacterial communities during the natural attenuation could provide new insights for understanding microbial ecosystem functioning in mine tailings. OTUs related to Sulfuriferula, Bacillus, Sulfurifustis, Gaiella, and Thiobacillus genera were the main contributors differentiating the bacterial communities between the different tailing sites. Multiple correlation analyses between bacterial communities and geochemical parameters indicated that $\mathrm{pH}, \mathrm{TOC}, \mathrm{TN}, \mathrm{As}$, $\mathrm{Pb}$, and $\mathrm{Cu}$ were the main drivers influencing the bacterial community structures. PICRUSt functional exploration revealed that the main functions were related to DNA repair and recombination, important functions for bacterial adaptation to cope with the multicontamination of tailings. Such information provides new insights to guide future metagenomic studies for the identification of key functions beyond metaltransformation/resistance. As well, our results offers novel outlooks for the management of 
61 bacterial communities during natural attenuation of multi-contaminated nonferrous metal(loid)

62 tailings sites.

63

64 Keywords: bacterial community succession; metal(loid)s; natural attenuation;

65 nonferrous metal(loid) tailings 


\section{Introduction}

Mine tailings repositories are unwanted and uneconomic materials from the mineral processing deposited exposure in the air. Tailings often contain elevated concentrations of metal(loid)s, which are potentially toxic (Lecumberri-Sanchez et al., 2014; Hudson-Edwards, 2016). Abandoned nonferrous metal(loid) tailings (i.e., facilities having no operator or successor) have received considerable attention around the world because they represent a risk for the environment and human health (Aleksandrovskii et al., 2015; COM, 2016). Guangxi (China) is one of the predominant nonferrous mining areas in the world (Rademaekers et al., 2011). It is a karst landform with many ecologically sensitive areas and is located upstream of the Pearl River Basin (China's third longest river and second largest by volume) (Wang et al., 2007). In Guangxi, different mining activities release waste that results in the formation of tailings with heterogeneous composition containing high concentrations of metal(loid)s and flotation reagents (Liu et al., 2018). Such level of multicomponent contamination is probably more serious than many other areas in the world (Zhu et al., 2018).

Biotic and abiotic processes modify the speciation of metal(loid)s and physicalchemical characteristics in tailings (Ye et al., 2017a; Ye et al., 2017b), which facilitate metal(loid)s permeation into soil, surface runoff, and air transportation (Deng et al., 2009; COM, 2016; Jiang et al., 2016; Yi et al., 2016; Yuan and Liu, 2016). Natural attenuation occurs when natural processes (including pedogenesis) are managed to recover an ecosystem to a point where the original fauna and flora are replicated (Clewell, 2000). Natural attenuation is more economical for re-purposing tailings compared to physical remediation, reclamation processes, or activated biochar addition on remediation (Lima et al., 2016, Ye et al., 2019). However, natural 
attenuation is a slow process that can take more than 100 years (Bradshaw, 1997;

Ciarkowska et al., 2016; Lima et al., 2016). With time, microbial colonization follows the modification of physical-chemical parameters (Giloteaux et al., 2013) due to biogeochemical processes (Haferburg and Kothe, 2007). Knowledge of the colonization of microbial communities during natural attenuation in mine tailings is limited (Bruneel et al., 2008; Volant et al., 2014; Zhan and Sun, 2014; Chao et al., 2016), particularly in the Guangxi area where only three tailings sites ( $\mathrm{Pb}-\mathrm{Zn}$ and $\mathrm{Mn}$ sites) have been investigated (Jin et al., 2015; Liu et al., 2014; Li et al., 2015). Recent results show that the distribution of bacterial communities in Guangxi nonferrous metal(loid)s tailings was best correlated with the combination of $\mathrm{pH}, \mathrm{Cu}, \mathrm{Pb}$, and $\mathrm{Mn}$, suggesting that these parameters influence the organization of bacterial communities (Liu et al., 2018). However, the modification of bacterial communities during natural attenuation in undisturbed nonferrous metal(loid) tailings is still uninvestigated. To address this research gap, we examined nonferrous mine tailings sites with different periods of abandonment (from 3 to 31 years) in the Guangxi mining area (Fig. 1 and Table S1), which have different geochemical characteristics. We hypothesize that temporal changes in biogeochemical factors, and bacterial diversity and metabolic functions are part of the natural attenuation process occurring in these tailings. The present study offers the possibility to examine the ecological changes, such as primary succession of microbial communities during natural attenuation. The objectives of this study were to: (1) investigate the structure of the microbial community (by MiSeq sequencing of 16S rRNA genes) and predict the metabolic functions in mine tailings, and (2) analyze the combined effects of geochemical factors including $\mathrm{pH}$, total organic carbon (TOC), total nitrogen (TN), total phosphorus (TP), and metal(loid)s content on the bacterial community structure. This 
study will provide a better understanding of microbial variations in nonferrous mine tailings, and useful information for the management of bacterial resources during natural attenuation of nonferrous metal(loid) tailings.

\section{Materials and methods}

\subsection{Site description and sampling}

Sampling was performed around Hechi City of Guangxi (China) (Fig. 1), which has a subtropical monsoon climate (Bi et al., 2016). Seven tailings sites with different composition and ages (ranging from three to 31 years old) were sampled to evaluate changes in bacterial communities during the natural attenuation (Fig. 1). The abandonment periods were determined using tailings pond records from the local Environmental Protection Agency. The types of tail sand at these seven tailings sites were mainly from $\mathrm{Sb}, \mathrm{Pb}-\mathrm{Zn}$, and $\mathrm{Sn}$ mining and smelting industries (Table S1).

These tailings were not treated with amendments or any remediation technology. There was no visible plant growth in all of the studied sites.

Surface samples $(0-10 \mathrm{~cm})$ with 3-10 subsamples for each site were collected in June 2016, using a wooden shovel according to EU international guideline (Hansen et al., 2007). All samples were directly placed into plastic pipes in cooler boxes (at $4^{\circ} \mathrm{C}$ ) and transported to laboratory at the University of Science and Technology Beijing within $2 \mathrm{~d}$ of sampling. After thorough homogenization, the samples were split into two parts. Approximately $500 \mathrm{~g}$ for each sample was then stored at $-20^{\circ} \mathrm{C}$ until DNA extraction. The remaining samples were used for geochemical analyses, and were stored at $4^{\circ} \mathrm{C}$. 


\subsection{Analysis of geochemical factors}

Samples were air-dried and analyzed according to the technical specifications for soil analysis for determination of $\mathrm{pH}$, total organic carbon (TOC), total nitrogen (TN), and total phosphorus (TP) as defined by the China National Agricultural Technology Extension Center (2006). The operating conditions for the TOC solid sample module (SSM-5000A, Shimadzu) were: the oven temperature, $680^{\circ} \mathrm{C}$, and the gas flow of high purity oxygen in TOC-V and SSM-5000A section, 150 and $500 \mathrm{~mL} / \mathrm{min}$, respectively. Samples were extracted with a solution of nitric, hydrochloric, and hydrofluoric acids $(5: 3: 2, \mathrm{v} / \mathrm{v} / \mathrm{v})$ in a microwave unit to determine the total metal(loid)s content (T-M). The acid soluble fraction of metal(loid)s (H-M) were analyzed using the Chinese method HJ/T299-2007. This fraction of H-M represents the leachable compartment that could be released into the environment. The leaching solution was prepared by adding $0.09 \mathrm{~mL}$ of a solution of sulfuric and nitric acids (2:1, $\mathrm{v} / \mathrm{v}$ ) and taken up to $1 \mathrm{~L}$ with ultra-pure water (Milli-Q Academic Lab Water System, Millipore, USA). Certified reference materials of soil samples (GBW 07405 (GSS-5)) and polymetallic ore samples (GBW 07162 (GSO-1)) were used for quality control. The limit of detection (LOD) for T-Ms was $>0.10 \times 10^{-3} \mathrm{mg} / \mathrm{kg}$ (Liu et al., 2018) and for H-Ms was $>0.10 \mathrm{mg} / \mathrm{kg}$ (Wang, 2018), according to the China Environmental Monitoring Technical guideline (HJ 168-2010). The recoveries were between 85\% $110 \%$. Samples were placed into $20 \mathrm{~mL}$ of leaching solution (pH $3.20 \pm 0.05$ ) and shaken for about $20 \mathrm{~h}$. Induced coupled plasma optical emission spectrometry (ICPOES) (iCAP 7000 SERIES, Thermo Scientific) was used to determine the metal(loid)s concentrations. The operating conditions were: auxiliary gas flow, 0.5 L/min; plasma gas stable time, $10 \mathrm{~min}$; ICP RF power, $1150 \mathrm{~W}$; and pump rate, 45 rpm. All the samples were sieved at 100-mesh size $(0.149 \mathrm{~mm}$, US standard) to 
determine the geochemical factors. The analyses were performed in duplicate to evaluate precision.

\subsection{MiSeq sequencing and data processing}

Genomic DNA was extracted using the SoilGen DNA Kit (CWBio, Bejing, China). DNA extraction kits allow to obtain high-quality DNA for PCR amplification and sequencing (Bordenave et al., 2004; Bordenave et al., 2008). The potential damage during DNA extraction are prevented by diluting metal(loid)s and eliminating them in the first steps of the procedure allowing molecular analyses of highly contaminated samples such as acid mine drainage (Giloteaux et al., 2010). The universal primer set 338F/806R amplified the V3-V4 region of the bacterial $16 \mathrm{~S}$ rRNA gene, and an 8 bp-tag was used for the sample identification (Liu et al., 2016). Polymerase chain reaction (PCR) amplification $(20 \mu \mathrm{L})$ was conducted in triplicate and contained 10 ng DNA template, $4 \mu \mathrm{L}$ of $5 \times$ FastPfu Buffer, $2 \mu \mathrm{L}$ of $2.5 \mathrm{mM}$ dNTPs, $0.2 \mu \mathrm{M}$ of each primer, $0.4 \mu \mathrm{L}$ FastPfu Polymerase, $0.2 \mu \mathrm{L}$ bovine serum albumin, and double-distilled water. PCR was started with an initial denaturation (3 $\min$ at $\left.95^{\circ} \mathrm{C}\right)$, followed by 28 cycles of denaturation $\left(30 \mathrm{~s}\right.$ at $\left.95^{\circ} \mathrm{C}\right)$, annealing $(30 \mathrm{~s}$ at $\left.55^{\circ} \mathrm{C}\right)$, and extension $\left(45 \mathrm{~s}\right.$ at $\left.72^{\circ} \mathrm{C}\right)$, and a final extension $\left(10 \mathrm{~min}\right.$ at $\left.72^{\circ} \mathrm{C}\right)$. Sequencing using a MiSeq platform was performed at a commercial facility (Shanghai Majorbio Bio-Pharm Technology Corporation, Shanghai, China).

All the 16S raw data were trimmed and filtered using Trimmomatic software (Manual v0.32), by trimming the average base quality region below $20 \mathrm{bp}$ (Trujillo et al., 2014). The paired-end reads were merged using FLASH software. The sequences assigned to chloroplasts, mitochondria or eukaryotes were removed in the pretreatment of raw reads. Bacterial operational taxonomic units (OTUs) were 
clustered with 97\% similarity using Usearch version 7.0 (http://drive5.com/uparse/) based on Silva Release128 (http://www.arb-silva.de). Taxonomy was assigned to OTUs using Qiime (http://qiime.org/scripts/assign_taxonomy.html) and ribosomal database project pipeline classification algorithm with a $70 \%$ confidence threshold (Nakayama, 2010). Alpha diversity indices (ace, Shannon, Simpson evenness and Boneh) and hierarchical clustering were calculated with Qiime. Circos-0.67-7 was used to perform the bacterial composition of each sample, and the distribution ratio of dominant bacteria in different samples. Functional prediction of bacterial communities was determined using PICRUSt, a well-documented tool to assign sequencing information based on $16 \mathrm{~S}$ input data to reveal the functions encoded in bacterial communities (Langille et al., 2013; Mchardy et al., 2013). Kyoto Encyclopedia of Genes and Genomes (KEGG) databases (e-value cut-off $10^{-5}$ ) were used for functional annotation and metabolism analyses (Mchardy et al., 2013; Kanehisa et al., 2014; Vrutika et al., 2016). The weighted nearest sequenced taxon index (NSTI) was calculated to assess the accuracy of PICRUSt analysis (Langille et al., 2013).

\subsection{Statistical analyses}

One-way ANOVA was applied to test the differences of geochemical factors; a level of $p<0.05$ was considered significant. The relationships between geochemical factors and alpha-diversity indexes were analyzed using Spearman correlation (SPSS v21). SIMPER analysis based on Bray-Curtis similarity measurement was used to test microbial differences in the tailings. Non-metric multidimensional scaling (NMDS) and distance-based redundancy analysis (db-RDA) analysis were conducted to test the correlation between bacterial communities and geochemical factors of tailings sites 
based on weighted normalized unifrac distance algorithm. The significance of geochemical factor was tested with Monte Carlo permutations (permu = 999).

Correlations of each bacterial community and each geochemical factor were calculated with $p$-values $<0.05$ and plotted as a heatmap. Network analysis was used to reflect the relationship between tailings sites and genera. After detection for genera (Gephi software), each module was represented by network correlation shared values of abundance profile by using modularity analysis. BIOENV analysis was used to determine the combined effects of geochemical factors on the metabolic pathways of bacterial communities. All the analyses were done using R software (v 3.4.1) unless otherwise stated.

\section{Results and discussion}

\subsection{Geochemical parameters of nonferrous mine tailings samples}

The $\mathrm{pH}$ in the seven studied tailings (Table S1) decreased with the period of abandonment, notably around $\mathrm{pH} 7.3$ at the youngest sites (from T_3Y to T_15Y), weakly acidic (pH 6.4) at site T_23Y, and extremely acidic $(\mathrm{pH} 2.6)$ at site T_31Y. This is consistent with other reports showing that the $\mathrm{pH}$ decreased in mine tailings undergoing more than 30 years of natural attenuation (Huang et al, 2011; Zhan and Sun, 2014; Ciarkowska et al., 2016). The gradual acidification of tailings could be caused by microbial mediated oxidative dissolution of pyrite $\left(\mathrm{FeS}_{2}\right)$ and other sulfide minerals exposed to air and water during natural attenuation (Huang et al., 2016). The low nutrient concentrations of $\mathrm{C} / \mathrm{N} / \mathrm{P}$ could nevertheless support the observed growth of microorganisms (described below), at least during the early phases of natural attenuation (Oudjehani, et al., 2002).

As expected at nonferrous metal(loid) tailings sites, the total metal(loid)s 
contents (T-M) were higher compared with the reported tailing sites in other regions around the world (Alakangas et al. 2010; Giloteaux et al., 2013; Bruneel et al., 2017).

The total arsenic content (T-As) was significantly correlated with total contents of $\mathrm{Cd}$, $\mathrm{Cr}$, and $\mathrm{Zn}($ Spearman rho $=$ from -0.82 to $0.86, p<0.04$; Table 1). Similar correlations between $\mathrm{As}, \mathrm{Zn}$, and $\mathrm{Cd}$ have been reported at mining- and aluminacontaminated soils (Zacháry et al., 2015).

The acid soluble fraction of metal(loid)s (H-M), representing the leachable fraction, was generally higher in tailing sites with 31 years abandonment (Table S1). Significant differences were also observed among the tailings sites, particularly for $\mathrm{H}$ $\mathrm{Cd}, \mathrm{H}-\mathrm{Cr}$, and $\mathrm{H}-\mathrm{Cu}$ (ANOVA, $p<0.05$, Table S1). Acid-soluble fraction in surface tailings represents the elements releasable that can migrate laterally or downwards via biotic and abiotic processes (Alakangas et al. 2010; Volant et al., 2014). The increased concentration of H-Ms and decreased $\mathrm{pH}$ with the age of abandonment suggested that a release of these metal(loid) was increasing over time, which was reported for other tailings (Walder and Chavez, 1995; Shu et al., 2001).

$$
<\text { Insert Table 1 }>
$$

\subsection{Microbial community diversity and composition of nonferrous mine tailings}

To determine the bacterial dynamics in abandoned tailings, a total of 1,481 bacterial OTUs were identified of all quality $16 \mathrm{~S}$ rRNA bacterial sequences $(265,487$ in total) after removing singletons and chimeric sequences (Tables S2 and S3). These 1,481 OTUs represent a high coverage $(99.8 \pm 0.1 \%$, Table S2), indicating that the sequencing data could reflect the vast majority of microbial diversity in the real environment. Furthermore, the Shannon diversity indexes were between 2.88 - 4.80, which were similar to an earlier report of a $\mathrm{Pb}-\mathrm{Zn}$ mining site (Chen et al., 2013). 
Bacterial diversity showed a decreasing relationship with the age of abandonment (Table S2 and Fig. S1). Nevertheless, the bacterial richness (Table S2) was up to eight times higher than that reported in an abandoned $\mathrm{Pb}-\mathrm{Zn}$ mine tailing site (Epelde et al., 2015), but no significant trend could be observed with abandonment age. This could be due to some more fundamental properties of tailings such as tailing matrix, mineral phases, and chemical composition since the tailings are from different types of mining and smelting industries (Fig. S1). In contrast, Chao et al. (2016) reported clear differences, as well as a time-dependent increase, in bacterial richness among REE (Rare Earth Elements) tailings sites that were abandoned for 3, 6, and 10 years. The richness of bacterial communities had a significant correlation with PD (phylogenetic diversity, $r h o=0.972, p=0.0002$; Table 1 ), which was statistically correlated with $\mathrm{TP}(r h o=0.79, p=0.036$; Table 1$)$. Overall, our results indicated a high genetic diversity in the Guangxi nonferrous mine tailings sites.

Over $98 \%$ of the OTUs could be assigned to a taxonomic phylum with $70 \%$ confidence; while over $56 \%$ of sequences were generally identified as no-rank or unclassified genera (Table S3), which was lower than that in a Sb-rich tailings dump (Xiao et al., 2016). Coupled with the high coverage and sequencing depth $(99.8 \pm 0.1$ $\%$, Table S2), this low assigned rate suggested these tailings sites had vast unidentified populations and microbial resources. These results were consistent with an earlier report showing that $58 \%$ of the sequences in a vanadium- and $17 \%$ in a gold- mine water from a South African mine, could not be assigned to a particular phylum (Keshri et al., 2015). Specifically, the shared phyla of tailings sites were Proteobacteria, Firmicutes, and Actionobacteria, accounting for $76 \%$ of total microbial community (Fig. 2), which confirmed recent studies by Liu et al. (2018) at abandoned nonferrous metal tailings sites, and by Chao et al (2016) at an abandoned 
REE tailings facility. These studies reported the same or similar dominant bacterial communities (at the phylum level), despite differences in $\mathrm{pH}$ and geochemical factors of the tailings.

$$
<\text { insert Fig. } 2>
$$

Among the total 507 genera identified from the seven tailings sites, 31 shared genera (relative abundance $>1 \%$ of total sequences at least in one tailing site) had different abundance among the seven tailings sites (Table S4). The differences observed were mainly due to different abundances of Sulfuriferula, Bacillus, Sulfurifustis, Gaiella, and Thiobacillus (Table 2). Sulfurifustis and Thiobacillus were the most abundant genera shared by tailings sites that were abandoned for $<15$ years (Table S4), indicating that these two genera may have contributed to sulfur- and iron oxidation at these sites. To date only three studies have detected Sulfurifustis that could be involved in sulfur oxidation (Kojima, et al., 2015; Kojima, et al., 2016; Umezawa, et al., 2016). Thiobacillus is capable of iron/sulfur-oxidization and carbon/nitrogen fixation in the early stages of the acidification processes of tailings (Yamanaka, 1996; Huang et al., 2016). Ralstonia, the most abundant genus in tailing sites abandoned for up to 23 years (29\%; Table S4), is a ubiquitous inhabitant of soil, freshwater and even ultrapure water in industrial systems (Gan, et al., 2012). This genus carries metal resistant genes, such as $c z c$ (resistance to cadmium, zinc, and cobalt) and ncc (cobalt and cadmium) (Mergeay, et al., 2010). Acidithiobacillus was most abundant at the extremely acidic tailing site $(\mathrm{pH}=2.0$, Table $\mathrm{S} 1)$ abandoned for 31 years (accounting for 29\% of total communities, Table S4). This genus was found to be able of carbon/nitrogen fixation, iron/sulfur oxidation, and arsenic oxidation (Huang et al., 2016). Acidithiobacillus may play an important role in the iron and arsenic oxidation in late acidification of the present tailing sites as reported for other 
tailings sites (Bruneel et al., 2005; Jorge et al., 2008; Huang et al., 2016).

$$
<\text { insert Table } 2>
$$

\subsection{Structure of tailings microbial communities}

Although the tailings sites shared bacterial populations, the whole bacterial structures were different (Fig. 3). Correlation analysis of geochemical factors and bacterial structure of tailings revealed four cluster groups: i) OTUs in T_4Y, T_8Y, and T_15Y correlated with TOC, ii) OTUs in T_6Y correlated with TN, T-As, and H$\mathrm{Pb}$, iii) OTUs in $\mathrm{T} \_23 \mathrm{Y}$ correlated with $\mathrm{pH}$ and $\mathrm{H}-\mathrm{Sb}$, and iv) OTUs in $\mathrm{T} \_31 \mathrm{Y}$ correlated with $\mathrm{pH}$ and TP (Fig. 3). These findings were consistent with earlier studies indicating that $\mathrm{pH}$, total metal(loid)s, and acid leachable metal(loid)s were correlated with microbial communities in tailings sites (Bruneel et al., 2017; Gupta et al., 2017; Hao et al., 2017). The acid leachable or bio-accessible fractions of metal(loid)s (such as $\mathrm{H}-\mathrm{Pb}$ ) can easily migrate with applications of acid rain or during natural acidification, and this process can be accelerated by the metabolic processes of adapted microbial communities (Haferburg and Kothe, 2007). For example, to survive in aquatic and soil environments with $\mathrm{Pb}^{2+}$ contamination, some microbes have developed $\mathrm{Pb}^{2+}$ resistance, involved extracellular binding, intracellular sequestration, active transport, and exclusion by forming a permeable barrier (Pan et al., 2017).

$<$ insert Fig. $3>$

Specific genera in each tailing site were also observed (Fig. 4A), suggesting that these tailings sites represent unique ecological niches during tailing colonization and natural attenuation. The distribution of these genera correlated with a combination of $\mathrm{pH}$, TOC, $\mathrm{H}-\mathrm{Pb}$, and T-As $(r \mathrm{M}=0.80, p=0.01$; Fig. 4B; Table 3), indicating that these four geochemical factors may play a key role in the distribution of microbial 
communities. In tailing sites with 3 years abandonment, Desulfurivibrio were specific (Fig. 4A), which always grow chemolithotrophically by sulfur/sulfide oxidation and dissimilate the reduction of nitrate/nitrite in slight alkali environments (Sorokin et al., 2008; Thorup et al., 2017). Although no plants were observed at the tailings sites, specific Rhizobium genus, beneficial for plant growth (Sujkowska-Rybkowska and Ważny, 2018), were observed in site T_23Y. This observation could be explained by aerial seeding by plants from the surrounding areas. The distribution of bacterial communities in $\mathrm{T} \_23 \mathrm{Y}$ was correlated with $\mathrm{pH}$ and $\mathrm{H}-\mathrm{Sb}$ content (Fig. 3B). In the extremely acidic $\mathrm{T} \_31 \mathrm{Y}$ tailing site, most of the specific genera, such as Acidithiobacillus and Acidiferrobacter, were related to sulfur/iron oxidation (Fig. 4A). These genera had significant and negative correlations with $\mathrm{pH}$, and significant positive correlations with $\mathrm{H}-\mathrm{As}, \mathrm{H}-\mathrm{Cr}$, and $\mathrm{H}-\mathrm{Cu}$ contents ( $p<0.001$, Fig. 5). This observation would be expected because Acidiferrobacter and Acidithiobacillus species participate in the metabolism of iron, sulfur, arsenic, and organic matter (Fan et al., 2016; Bruneel et al., 2017). In addition, acidophilic Acidithiobacillus-related sequences can generate AMD waters, and oxidize the ferrous sulfate to immobilize $\mathrm{As}^{5+}$ in arsenic-contaminated soil (Huang et al., 2016; Yang et al., 2017), suggesting that this species may have an important ecological role for increasing metal sulfide dissolution and controlling AMD production. The frequently encountered distribution and numerous dominance of iron/sulfur-oxidizing and metal-related genera in acidic environments during the long process of natural attenuation reflects their potential role in the natural attenuation of metal(loid)s and generating AMD at tailings sites (Chen et al., 2013; Huang et al., 2016).

$$
\begin{aligned}
& <\text { insert Fig. } 4> \\
& <\text { insert Fig. } 5>
\end{aligned}
$$


Chao et al. (2016) showed that soil microbiota can vary significantly at different

abandoned REE tailing sites, by the co-development of microbial and plant

communities during natural attenuation. These studies showed that site-specific

factors induced microbial changes within subgroups of abandoned sites, which is

consistent with our findings. However, the tailing samples in the Chao et al. (2016)

contained vegetal material compared to the present study. Therefore, it is not known if the microbial changes described in the Chao et al. study are related to site factors or plant development, or both. Ridl et al. (2016) demonstrated that plants, and not the use of fertilizers, were the drivers of microbial community structure in contaminated soil, with the magnitude of effect depending on the type of plant species. Based on our study, in which plants were not observed, it is likely that microbial changes were caused by geochemical factors and the extremely unfavorable growing conditions (such as low C/N/P contents and high metal(loid)s concentrations).

\subsection{Potential functional metabolism of bacterial communities}

For successful survival and adaptation to a multi-contaminated environment, which constitutes an evolutionary challenge for organisms, sophisticated resistance strategies and mechanisms are required for microbial succession (Guan et al., 2017). PICRUSt analysis was used for exploring the possible metabolism pathways associated with the detoxification of metal(loid)s and transport of geochemical elements in tailings undergoing natural attenuation. The NSTI (nearest sequenced taxon index) values in the present study were less than 0.18 (except at site T_3Y) indicating that the PICRUSt prediction analysis was accurate (Table S2). The relationship between the KEGG pathways and bacterial community structures 
revealed that each tailing site had its specific functional pathways (Fig. 6). KEGG pathways related to DNA replication and repair, and recombination proteins were mainly clustered close to tailing sites with 31 years natural attenuation (Fig. 6). As well, the distribution of these predicted functional metabolic pathways was strongly correlated with $\mathrm{pH}$, TOC, TP, T-As, T-Zn, and $\mathrm{H}-\mathrm{Cr}(r=0.98$, Table S7). It is known that environmental stresses (such as $\mathrm{pH}, \mathrm{As}$, and $\mathrm{Pb}$ ) can directly or indirectly damage the structure of DNA, which results in the mismatch of nucleic acids, and DNA degradation, thus affecting the diversity and structure of microorganisms (AmaralZettler et al., 2011; Bruneel et al., 2017; Guan et al., 2017; Hao et al., 2017). These in turn could ultimately lead to microbial cell injury, protein degradation, and gene mutation (Dai et al., 2013; Guan et al., 2017). It is possible that the DNA repair system participated in the sensitive targets of microbial metal(loid)s toxicity observed in our study, resulting in the adaptation of bacterial communities to the extreme tailings environments.

SIMPER analysis using the KEGG database indicated that the metabolic pathways directly related to ATP, methane, nitrogen, and energy generation (such as $\mathrm{ABC}$ transporters) also contributed to the differences of bacterial community structures in the seven tailings sites (Table S5 and S6). ABC transporters constitute large amounts of membrane proteins and could transport many diverse substrates, such as metal(loid)s and secondary metabolites (Theodoulou and Kerr, 2015). As discussed above, metal(loid) oxidation-related genus of Acidithiobacillus could also encode the $\mathrm{ABC}$ transporter genes involved with zinc ion transport (Hou et al., 2012). Previous studies also confirmed that genetic expression of iron/sulfur-oxidizing and metal(loid) tolerance may propagate through horizontal gene transfer (Sandoval et al., 2004; Bouzat and Hoostal, 2013), which enables bacterial communities to acquire a 
gene (or genes) favoring the adaptation of bacterial communities to extreme environments during natural attenuation. To better understand the mechanisms of bacterial communities undergoing natural attenuation in nonferrous metal tailings, further analyses combining geochemical parameters (such as inorganic $\mathrm{C}$, sulfides/sulfates/iron contents, and the neutralization capacity) with metatranscriptomic and metagenomic analyses will provide useful information.

\section{Conclusions}

Our study provides greater insight into the temporal dynamics of bacterial communities during natural attenuation. Each tailing site was identified as a unique ecological niche. Tailings abandoned for $\leq 15$ years were in a pre-acidification phase and undergoing acidification. Tailings $\geq 23$ years abandonment had higher acid soluble As concentrations and the metal(loid)s that may represent a risk for human health and the environment (COM, 2016; Hudson-Edwards, 2016). A gradual succession of bacterial genera in the tailings sites was observed suggesting that the bacterial communities become more acidophilic and metal-resistant. Functional metabolic pathways of DNA repair and recombination may be the main potential mechanisms for the microbes to cope with oligotrophic and extreme tailings habitats. The present study suggests that although natural attenuation may be a key strategy towards sustainability, careful monitoring of abandoned tailings sites should be considered as early as possible, to enable the timely management of any potential environmental risks present at these sites. 


\section{Acknowledgments}

This work was funded by the International Key Project from National Natural Science Foundation of China (41720104007), and Projects of Natural Science Foundation of China (41573080, U1402234, 41711530030, 41711530150, 41711530224), Public welfare project of Chinese Ministry of Environmental Protection (201509049), International key project of Ministry of Science and Technology of China (S2016G2135), and Fundamental Research Funds for the Central Universities (FRFOT-16-025). We also acknowledge the support of the Centre National de la Recherche Scientifique (CNRS PRC1416, France), a Royal Society Newton Mobility Grant (IE161198), and National Natural Science Foundation International Joint collaboration China-Sweden (41430106).

\section{Appendix A. Supporting information}

Supplementary data related to this article can be found at the website of Environmental Pollution.

\section{References}

Alakangas L., Lundberg A., Öhlander B., 2010. Estimation of temporal changes in oxidation rates of sulphides in copper mine tailings at Laver, northern Sweden. Sci Total Environ 408, 1386-1392.

Aleksandrovskii, A.L., Aleksandrovskaya, E.I., Dolgikh, A.V., 2015. Soils and cultural layers of ancient cities in the south of European Russia. Eurasian Soil Sci 48, 1171-1181.

Amaral-Zettler, L.A., Zettler, E.R., Theroux, S.M., et al., 2011. Microbial community structure across the tree of life in the extreme Río Tinto. ISME J 5, 42-50.

Bi, X., Zhang, F., Shi, J., et al., 2016. Climatic change characteristics of Hechi city in the last 56 years. Water Transf. Water Sci Technol 14, 105-110.

Bouzat, J.L., Hoostal, M.J., 2013. Evolutionary analysis and lateral gene transfer of 
two-component regulatory systems associated with heavy-metal tolerance in bacteria. J Mol Evol 76, 267-279.

Bordenave, S., Fourçans, A., Blanchard, S., et al., 2004. Structure and functional analyses of bacterial communities changes in microbial mats following petroleum exposure. Ophelia 58, 195-203.

Bordenave, S., Goñi-Urriza, M., Vilette, C., et al., 2008. Diversity of ringhydroxylating dioxygenases in pristine and oil contaminated microbial mats at genomic and transcriptomic levels. Environ Microbiol 10, 3201-3211.

Bradshaw, A., 1997. Restoration of mined lands - using natural processes. Ecol Eng 8, 255-269.

Bruneel, O., Duran, R., Koffi, K., et al., 2005. Microbial diversity in a pyrite-rich tailings impoundment (Carnoulès, France). Geomicrobiol J 22, 249-257.

Bruneel, O., Mghazli, N., Hakkou, R., et al., 2017. In-depth characterization of bacterial and archaeal communities present in the abandoned Kettara pyrrhotite mine tailings (Morocco). Extremophiles 21, 671-685.

Bruneel, O., Pascault, N., Egal, M., et al., 2008. Archaeal diversity in a Fe-As rich acid mine drainage at Carnoulès (France). Extremophiles 12, 563-571.

Chao, Y., Liu, W., Chne, Y., et al., 2016. Structure, variation, and co-occurrence of soil microbial communities in abandoned sites of a rare earth elements mine. Environ Sci Technol 50, 11481-11490.

Chen, L., Li, J., Chen, Y., et al., 2013. Shifts in microbial community composition and function in the acidification of a lead/zinc mine tailings. Environ Microbiol $15,2431-2444$.

China National Agricultural Technology Extension Center, 2006. Technical specification for soil analysis (second edition). Beijing: China Agriculture Press (in Chinese).

Ciarkowska, K., Gargiulo, L., Mele, G., 2016. Natural restoration of soils on mine heaps with similar technogenic parent material: A case study of long-term soil evolution in Silesian-Krakow Upland Poland. Geoderma 261, 141-150.

Clewell, A.F., 2000. Restoration of natural capital. Restor. Ecol. 8, 1-11.

Commission of the European Communities (COM), 2016. 593 Final. Proposal for a directive of the European parliament and of the council on the management of waste from the extractive industries. 2016/0280 (COD), Commission of the European Communities, Brussels.

Dai, M., Martin, J.M., Cauwet, G., 2013. The significant role of colloids in the transport and transformation of organic carbon and associated trace metals $(\mathrm{Cd}$, $\mathrm{Cu}$ and $\mathrm{Ni}$ ) in the Rhône delta (France). Moussons: Recherche en Sciences Humaines sur l'Asie du Sud-Est 51, 203-209. 
Deng, C., Wang, S., Li, F., 2009. Research on soil multi-media environmental pollution around $\mathrm{a} \mathrm{Pb}-\mathrm{Zn}$ mining and smelting plant in the karst area of Guangxi Zhuang Autonomous Region, Southwest China. Acta Geochimica 28, 188-197.

Epelde, L., Lanzén, A., Blanco, F., et al., 2015. Adaptation of soil microbial community structure and function to chronic metal contamination at an abandoned Pb-Zn mine. FEMS Microbiol Ecol 91, 1-11.

Fan, M., Lin, Y., Huo, H., et al., 2016. Microbial communities in riparian soils of a settling pond for mine drainage treatment. Water Res 96, 198-207.

Gan, H., Chew, T., Tay, Y., et al., 2012. Genome sequence of Ralstonia sp. strain pba, a bacterium involved in the biodegradation of 4-aminobenzenesulfonate. $\mathrm{J}$ Bacteriol 194, 5139-40.

Giloteaux, L., Goñi-Urriza, M., Duran, R., 2010. Nested PCR and new primers for analysis of sulfate-reducing bacteria in low-cell-biomass environments. Appl Environ Microbiol 76, 2856-2865.

Giloteaux, L., Duran, R., Casiot, C., et al., 2013. Three-year survey of sulfatereducing bacteria community structure in Carnoulès acid mine drainage (France), highly contaminated by arsenic. FEMS Microbiol Ecol 83, 724-737.

Guan, N., Li, J., Shin, H.D., et al., 2017. Microbial response to environmental stresses: From fundamental mechanisms to practical applications. Appl Microbiol Biotechnol 101, 1-18.

Gupta, A., Dutta, A., Sarkar, J., et al., 2017. Metagenomic exploration of microbial community in mine tailings of Malanjkhand copper project, India. Genomics Data 12, 11-13.

Haferburg G., Kothe E, 2007. Microbes and metals: interactions in the environment. J Basic Microbiol 47, 453-467.

Hansen, J., Grøn, C., Lund, U., et al. Uncertainty from sampling: workshop to launch a Nordtest handbook on sampling uncertainty estimation and control. Accredit Qual Assur 2007, 12(7):377-381.

Hao, X., Liang, Y., Yin, H., et al., 2017. Thin-layer heap bioleaching of copper flotation tailings containing high levels of fine grains and microbial community succession analysis. Int J Min Met Mater 24, 360-368.

Hou, D., Miao, B., Wang, Y., et al., 2012. Identification and analysis of zinc transport genes in Acidithiobacillus ferrooxidans. Chin J Nonferrous Met 2012, 22, 1497 1502.

Huang L., Kuang J., Shu W., 2016. Microbial ecology and evolution in the acid mine drainage model system. Trends Microbiol 24, 581-593.

Huang, L., Zhou, W., Hallberg, K., et al., 2011. Spatial and temporal analysis of the microbial community in the tailings of a $\mathrm{Pb}-\mathrm{Zn}$ mine generating acidic drainage. 


\section{Appl Environ Microbiol 77, 5540-4.}

Hudson-Edwards, K., 2016. Tackling mine wastes. Science 352, 288-290.

Jiang, P., Lu, S., Tao, R., 2016. On analysis and strategies for tailing ponds in Guangxi. Shanxi Architecture 42, 58-60.

Jin, Z., Li, Z., Li, Q., et al., 2015. Canonical correspondence analysis of soil heavy metal pollution, microflora and enzyme activities in the $\mathrm{Pb}-\mathrm{Zn}$ mine tailing dam collapse area of Sidi village, SW China. Environ Earth Sci 73, 267-274.

Jorge, V., Pedroso, I., Quatrini, R., et al., 2008. Acidithiobacillus ferrooxidansmetabolism: from genome sequence to industrial applications. BMC Genomics 9, 597-597.

Kanehisa, M., Goto, S., Sato, Y., et al., 2014. Data, information, knowledge and principle: back to metabolism in KEGG. Nucleic Acids Res 42, 199-205.

Keshri, J., Mankazana, B.B., Momba, M.N., 2015. Profile of bacterial communities in South African mine-water samples using Illumina next-generation sequencing platform. Appl Microbiol Biot 99, 3233-3242.

Kojima, H, Shinohara, A, Fukui, M., 2015. Sulfurifustis variabilis gen. nov. sp. nov. a novel sulfur oxidizer isolated from a lake, and proposal of Acidiferrobacteraceae fam. nov. and Acidiferrobacterales ord. nov. Int J Syst Evol Microbiol 65, 37093713.

Kojima, H, Watanabe, T, Fukui, M., 2016. Sulfuricaulis limicola gen. nov. sp. nov. a sulfur oxidizer isolated from a lake. Int J Syst Evol Microbiol 66, 266-270.

Langille, M.G., Zaneveld, J., Caporaso, J., et al., 2013. Predictive functional profiling of microbial communities using 16S rRNA marker gene sequences. Nat Biotechnol 31, 814-21.

Lecumberri-Sanchez, P., Romer, R.L., Lüders, V., et al, 2014. Genetic relationship between silver-lead-zinc mineralization in the Wutong deposit, Guangxi province and Mesozoic granitic magmatism in the Nanling belt, southeast China. Miner Deposita 49, 353-369.

Li, Q., Hu, Q., Zhang, C., 2015. The effect of toxicity of heavy metals contained in tailing sands on the organic carbon metabolic activity of soil microorganisms from different land use types in the karst region. Environ Earth Sci 74, 67476756.

Lima, A.T., Mitchell, K., O'Connell, D.W., et al., 2016. The legacy of surface mining: remediation, restoration, reclamation and rehabilitation. Environ Sci Policy 66, 227-233.

Liu, J., Yao, J., Wang, F., et al., 2018. China's most typical nonferrous organic-metal facilities own specific microbial communities. Sci Rep 1, 12570-12580.

Liu, J., Zhang, X., Li, T., et al., 2014. Soil characteristics and heavy metal 
accumulation by native plants in a Mn mining area of Guangxi, South China. Environ Monit Assess 4, 2269-2279.

Liu, J., Zhang, M., Zhang, R., et al., 2016. Comparative studies of the composition of bacterial microbiota associated with the ruminal content, ruminal epithelium and in the faeces of lactating dairy cows. Microb Biotechnol 9, 257-268.

Mchardy, I.H., Goudarzi, M., Tong, M., et al., 2013. Integrative analysis of the microbiome and metabolome of the human intestinal mucosal surface reveals exquisite inter-relationships. Microbiome 1, 17-27.

Mergeay, M., Monchy, S., Vallaeys, T., 2010. Ralstonia metallidurans, a bacterium specifically adapted to toxic metals: towards a catalogue of metal-responsive genes. FEMS Microbiol Rev 27, 385-410.

Nakayama, J., 2010. Pyrosequence-based 16S rRNA profiling of gastrointestinal microbiota. Biosci Microflora 29, 83-96.

Oudjehani, K., Zagury, G.J., Deschênes, L., 2002. Natural attenuation potential of cyanide via microbial activity in mine tailings. Appl Microbiol Biot 58, 409-415.

Pan, X., Chen, Z., Li, L., et al., 2017. Microbial strategy for potential lead remediation: A review study. World J. Microb. Biotechnol. 33, 35-42.

Rademaekers, K., Netherlands, E., Smakman, F., et al., 2011. Competitiveness of the EU non-ferrous metals industries FWC sector competitiveness studies (final report). European Commission, Directorate-General Enterprise and Industry. http://ec.europa.eu/competition/consultations/2011_questionnaire_emissions_tra ding/unicobre_annex1_en.pdf.

Ridl, J., Kolář, Michal, H., et al., 2016. Plants rather than mineral fertilization shape microbial community structure and functional potential in legacy contaminated soil. Front Microbiol 7. doi: 10.3389/fmicb.2016.00995.

Sandoval, P., Gabriel León, Isabel Gómez, et al., 2004. Transfer of RPS14 and RPL5 from the mitochondrion to the nucleus in grasses. Gene 324, 139-147.

Shu, W., Ye, Z., Lan, C., et al., 2001. Acidification of lead/zinc mine tailings and its effect on heavy metal mobility. Environ Int 26, 389-394.

Sorokin, D.Y., Tourova, T.P., Mußmann, M., et al., 2008. Dethiobacter alkaliphilus gen. nov. sp. nov., and Desulfurivibrio alkaliphilus gen. nov. sp. nov.: two novel representatives of reductive sulfur cycle from soda lakes. Extremophiles 12, 431439.

Sujkowska-Rybkowska, M., Ważny, R., 2018. Metal resistant rhizobia and ultrastructure of Anthyllis vulneraria nodules from zinc and lead contaminated tailing in Poland. Int J Phytoremediat 20, 709-720.

Theodoulou, F.L., Kerr, I.D., 2015. ABC transporter research: going strong 40 years on. Biochem Soc T 43, 1033-1040. 
Thorup, C., Schramm, A., Findlay, A.J., et al., 2017. Disguised as a sulfate reducer: growth of the Deltaproteobacterium Desulfurivibrio alkaliphilus by sulfide oxidation with nitrate. Mbio 8, e00671-17.

Trujillo, D.I., Silverstein, K.A.T., Young, N.D., 2014. Genomic characterization of the LEED..PEEDs, a gene family unique to the Medicago lineage. G3-Genes Genom. Genet 4, 2003-2012. http://doi.org/10.1534/g3.114.011874

Umezawa, K., Watanabe, T., Miura, A., et al., 2016. The complete genome sequences of sulfur-oxidizing Gammaproteobacteria Sulfurifustis variabilis, skN76 T, and Sulfuricaulis limicola, HA5 T. Stand Genomic Sci 11, 71-79.

Volant, A., Bruneel, O., Desoeuvre, A., et al., 2014. Diversity and spatiotemporal dynamics of bacterial communities: physicochemical and other drivers along an acid mine drainage. FEMS Microb Ecol 90, 247-263.

Vrutika, P., Anukriti, S., Rup, L., et al., 2016. Response and resilience of soil microbial communities inhabiting in edible oil stress/contamination from industrial estates. BMC Microbiol 16, 50-64.

Walder, I.F., Chavez, W.X., 1995. Mineralogical and geochemical behavior of mill tailing material produced from lead-zinc skarn mineralization, Hanover, Grant County, New Mexico, USA. Environ Geol 26, 1-18.

Wang, J., Yang, D., Yu, S., et al., 2007. Analysis on Karst rocky desertification in upper reaches of Pearl River based on remote sensing. Sci Soil Water Conserv 5, $1-6$.

Wang, T., 2018. Speciation changes of heavy metals in the process of tailings ecological restoration in northwest Guangxi. MSc Thesis. University of Science and Technology Beijing, Beijing, China.

Xiao, E., Krumins, V., Dong, Y., et al., 2016. Microbial diversity and community structure in an antimony-rich tailings dump. Appl Microbiol Biotechnol 100, 7751-7763.

Yamanaka, T., 1996. Mechanisms of oxidation of inorganic electron donors in autotrophic bacteria. Plant Cell Physiol 37, 569-574.

Yang, Z., Wu, Z., Liao, Y., et al., 2017. Combination of microbial oxidation and biogenic schwertmannite immobilization: a potential remediation for highly arsenic-contaminated soil. Chemosphere 181, 1-8.

Ye, S., Zeng, G., Wu, H., et al., 2017a. Biological technologies for the remediation of co-contaminated soil. Crit Rev Biotechnol 37, 1062-1076.

Ye, S., Zeng, G., Wu, H., et al., 2017b. Co-occurrence and interactions of pollutants, and their impacts on soil remediation-a review. Crit Rev Env Sci Tec 47, 15281553.

Ye, S., Zeng, G., Wu, H., et al., 2019. The effects of activated biochar addition on 
remediation efficiency of co-composting with contaminated wetland soil. Resour Conserv Recy 140, 278-285.

Yi, R., Cai, D., Zhang, Y., et al., 2016. Evaluation of biomonitoring methods using benthic biatoms in Longjiang River, China. Chinese J Environ Eng 10, 33453353.

Yuan, L., Liu Y.S., 2016. The leaching principles of heavy metals in Pb-Zn tailings in simulation acid rain. Environ Eng 30, 586-590.

Zacháry, D., Jordan, G., Völgyesi, P., et al., 2015. Urban geochemical mapping for spatial risk assessment of multisource potentially toxic elements - a case study in the city of Ajka, Hungary. J Geochem Explor 158, 186-200.

Zhan, J., Sun, Q.Y., 2014. Development of microbial properties and enzyme activities in copper mine wasteland during natural restoration. Catena 116, 86-94.

Zhu, X., Yao, J., Wang, F., et al., 2018. Combined effects of antimony and sodium diethyldithiocarbamate on soil microbial activity and speciation change of heavy metals. Implications for contaminated lands hazardous material pollution in nonferrous metal mining areas. J Hazard Materials 2018, 349, 160-167. 
673

674

675

676

677

678

679

680

681

682

683

684

\section{Figure legends}

Fig. 1. Sample location map (top left) and aerial photograph (top right) of the seven tailings sites (T_3Y to T_31Y) close to Hechi city (• shown on map), Guangxi (China), where the surface samples $(\odot$ on aerial photo) were collected for the present study. Field photographs of tailing sample sites are shown in the bottom panels $\left(\mathrm{T}_{-} 3 \mathrm{Y}\right.$ to $\left.\mathrm{T} \_31 \mathrm{Y}\right)$. As an example, $\mathrm{T} \_3 \mathrm{Y}$ corresponds to the tailing sample code. $\mathrm{T} \_3 \mathrm{Y}$ means the tailing samples were taken from a three years old abandoned site (not-used).

Fig. 2. Relative abundances of bacterial phyla in the seven abandoned tailings sites. The relative abundances of Alpha-, Beta-, Gamma-, Delta- Proteobacteria, and Actinobacteria classes are shown in the insert diagram.

Fig. 3. (A) Non-metric multidimensional scaling (NMDS) analysis of bacterial communities in seven tailings sites at genus level. (B) Distance-based redundancy analysis (db-RDA) of genus and selected geochemical factors in seven tailings sites. Both NMDS and db-RDA analysis were based on the weighted normalized unifrac distance algorithms. Direction and magnitude of arrows indicate the correlation of geochemical factors and genera.

Fig. 4. (A) Network analysis for the detected bacterial communities (genus level) in different tailings sites. Color was coded by tailings sites. Each node indicates one genus. Colors of node represent the different major phyla. The size the species-node denotes abundance of species. Black nodes represented the no_rank/un-classified genera which were shared by tailings sites. Light green nodes represented the no_rank/un-classified genera, which were specific in different tailings sites. The 
degree of node was assessed by the numbers of nodes connected directly to that node. The more lines on the node denotes the higher degree of correlation between the sites and other genera. (B) The sub-network analysis for modularity of genera. Colors of node represent the different module. Node size is proportional to the modularity class. The nodes without labels represented the no_rank/un-classified genera. B. P., Burkholderia-Paraburkholderia

Fig. 5. Correlation analysis based on the Pearson test showing the relation between the geochemical factors and the relative abundance of bacterial communities at the phylum (A) and genus (B) levels. Only the top 30 bacterial communities are shown in this figure. Color key for the correlation values is shown on the right panel inset; positive correlations are in red text, negative correlations are in green, non-significant correlations are shown in white. $* 0.01<p \leq 0.05, * * 0.001<p \leq 0.01, * * * p \leq 0.001$

Fig. 6 Principal Components Analysis (PCA) for bacterial community structure and KEGG metabolic functional pathways based on 16S rRNA sequencing reads. 


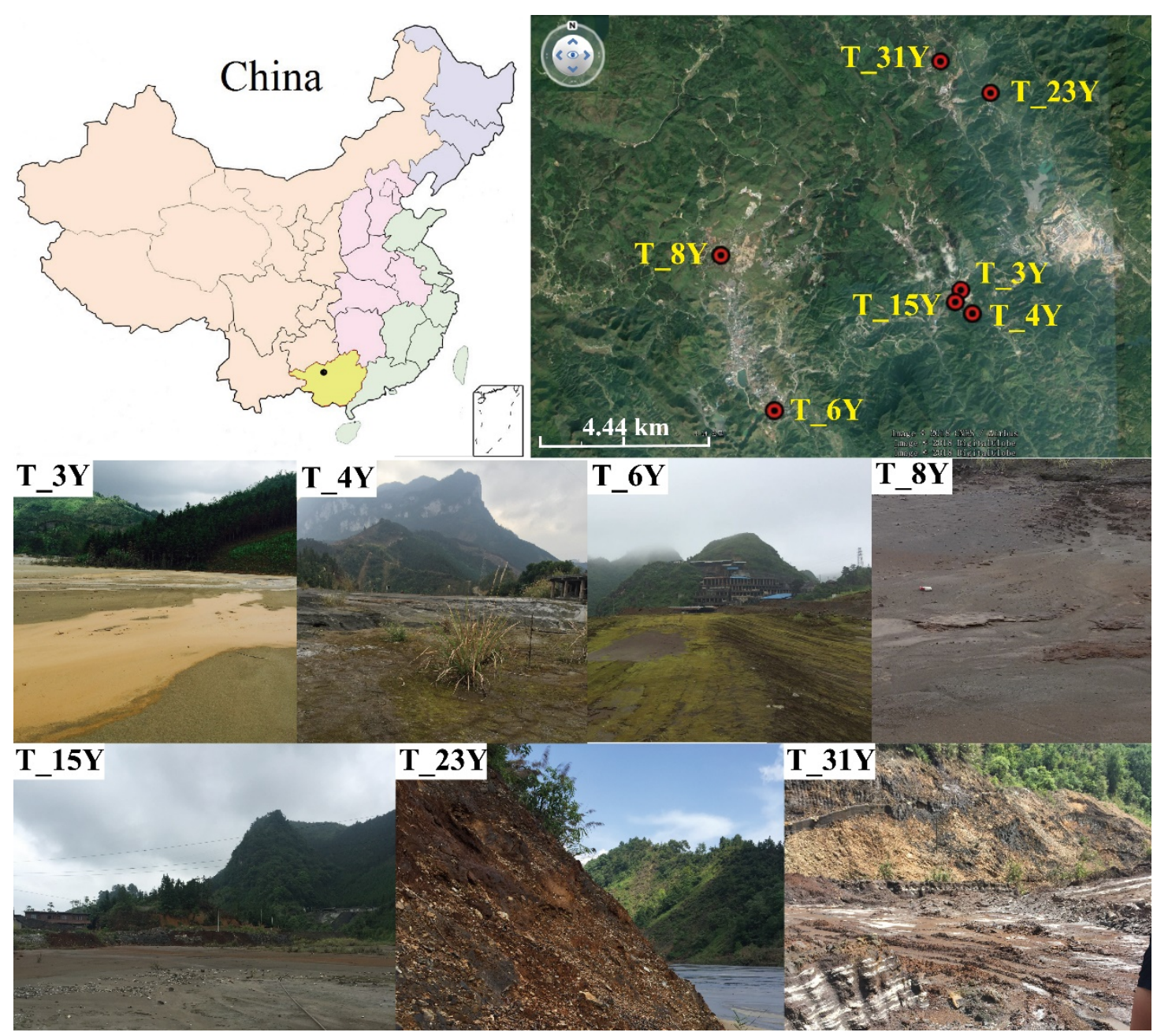

Fig. 1. Sample location map (top left) and aerial photograph (top right) of the seven tailings sites (T_3Y to T_31Y) close to Hechi city (• shown on map), Guangxi (China), where the surface samples ( $\odot$ on aerial photo) were collected for the present study. Field photographs of tailing sample sites are shown in the bottom panels ( $T$ _3Y to T_31Y). As an example, T_3Y corresponds to the tailing sample code. T_3Y means the tailing samples were taken from a three years old abandoned site (not-used). 


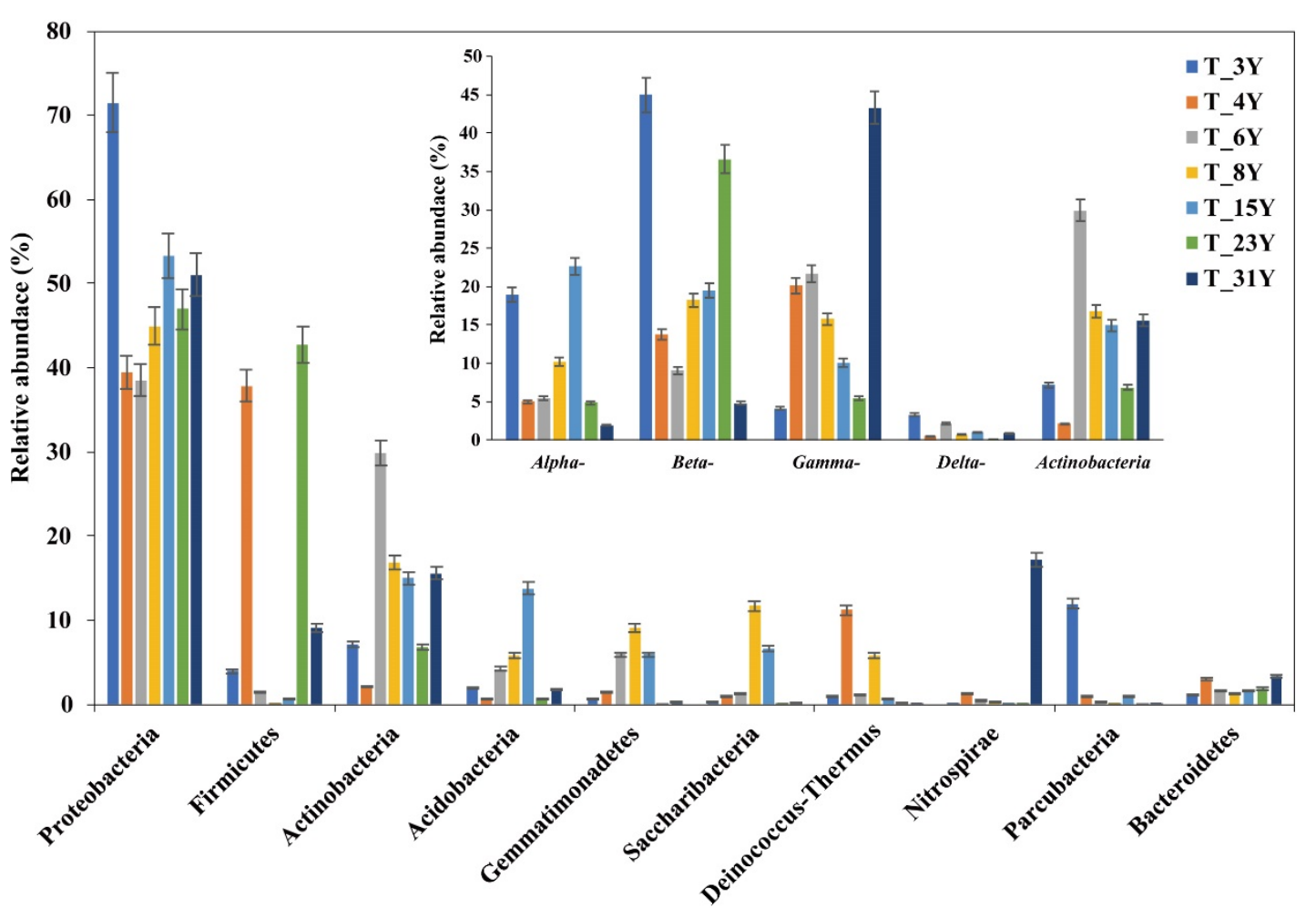

722 Fig. 2. Relative abundance of bacterial communities at phylum level in the seven 723 abandoned tailings sites. Relative abundance of Alpha-, Beta-, Gamma-, Delta-

724 Proteobacteria-related and Actinobacteria classes are shown in the map inset. 

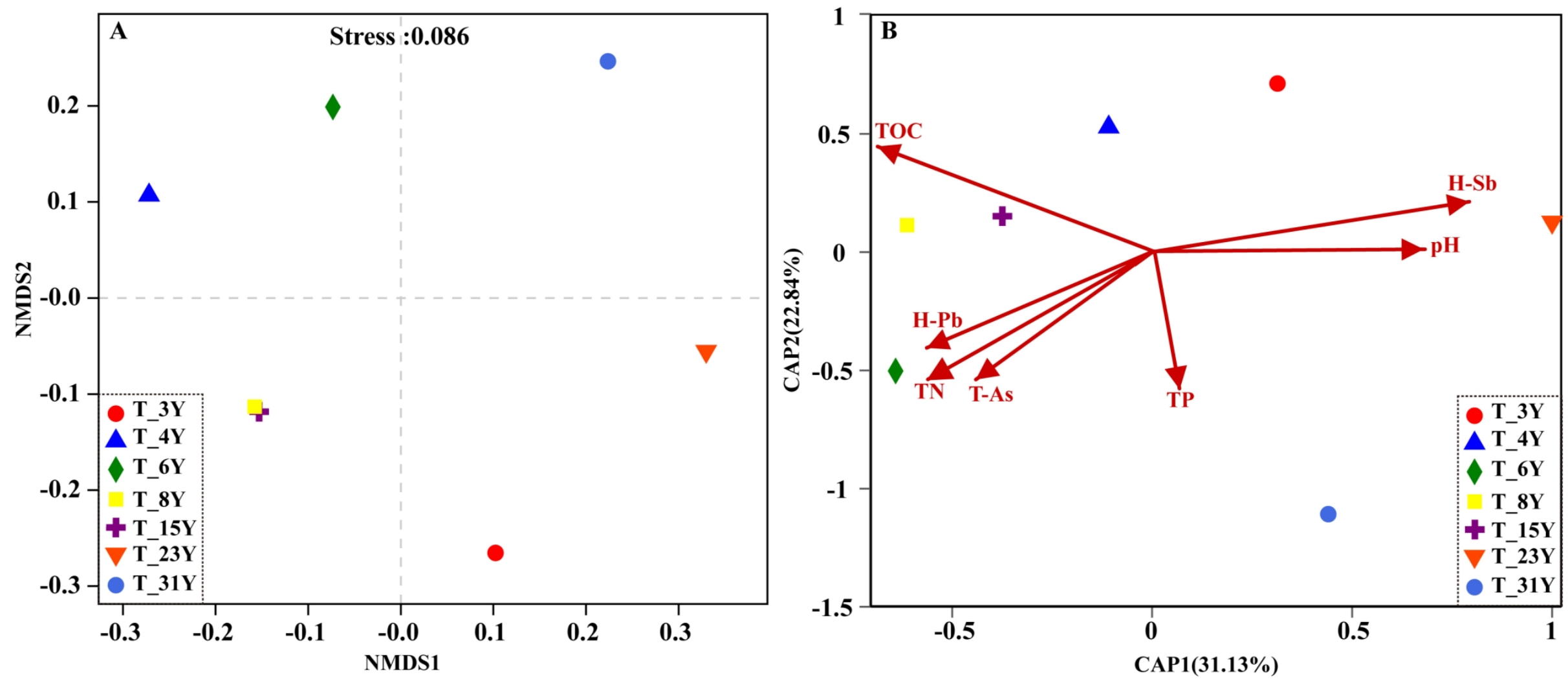

Fig. 3. (A) Non-metric multidimensional scaling (NMDS) analysis of bacterial communities in seven tailings sites at genus level. (B) Distancebased redundancy analysis (db-RDA) of genus and selected geochemical factors in seven tailings sites. Both NMDS and db-RDA analysis were based on the weighted normalized unifrac distance algorithms. Direction and magnitude of arrows indicate the correlation of geochemical factors and genera. 


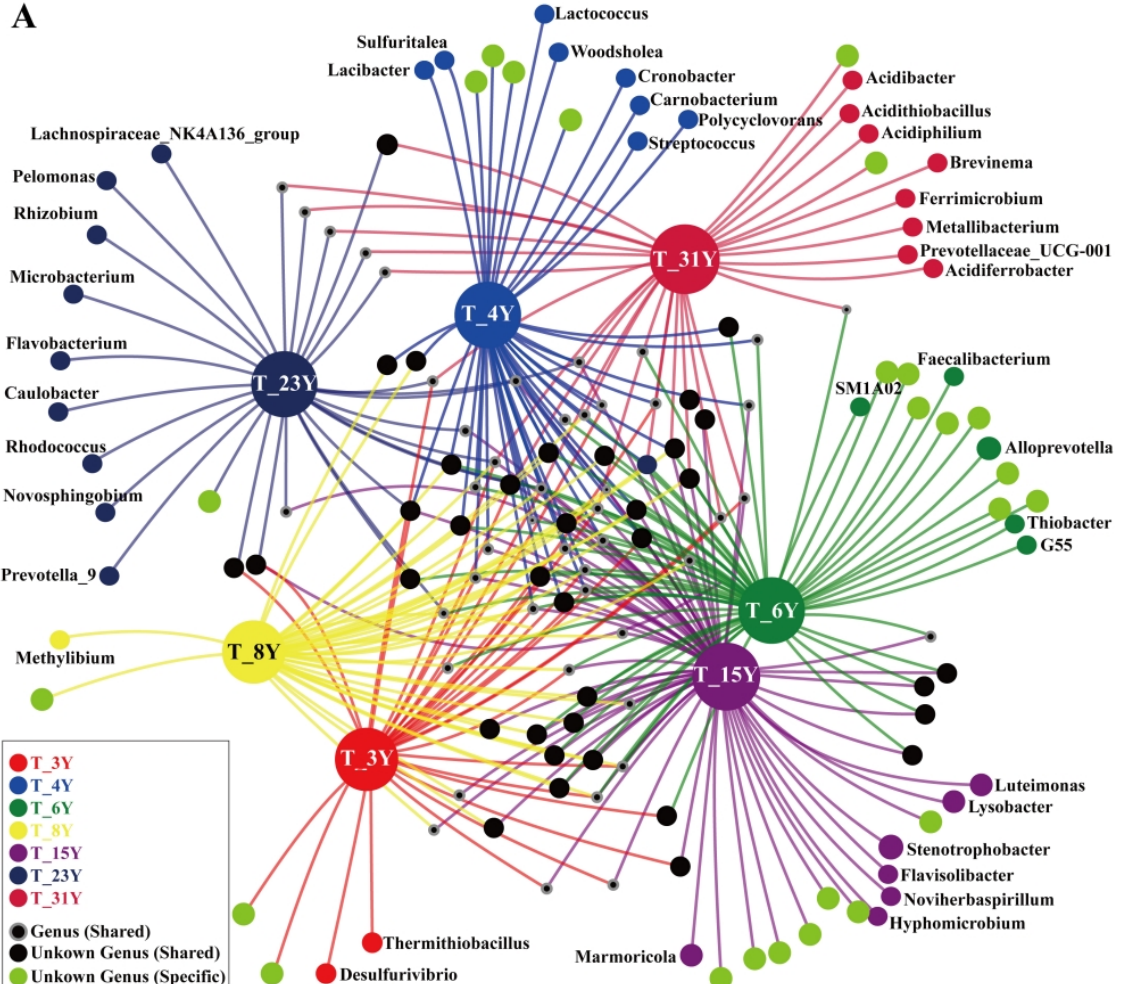

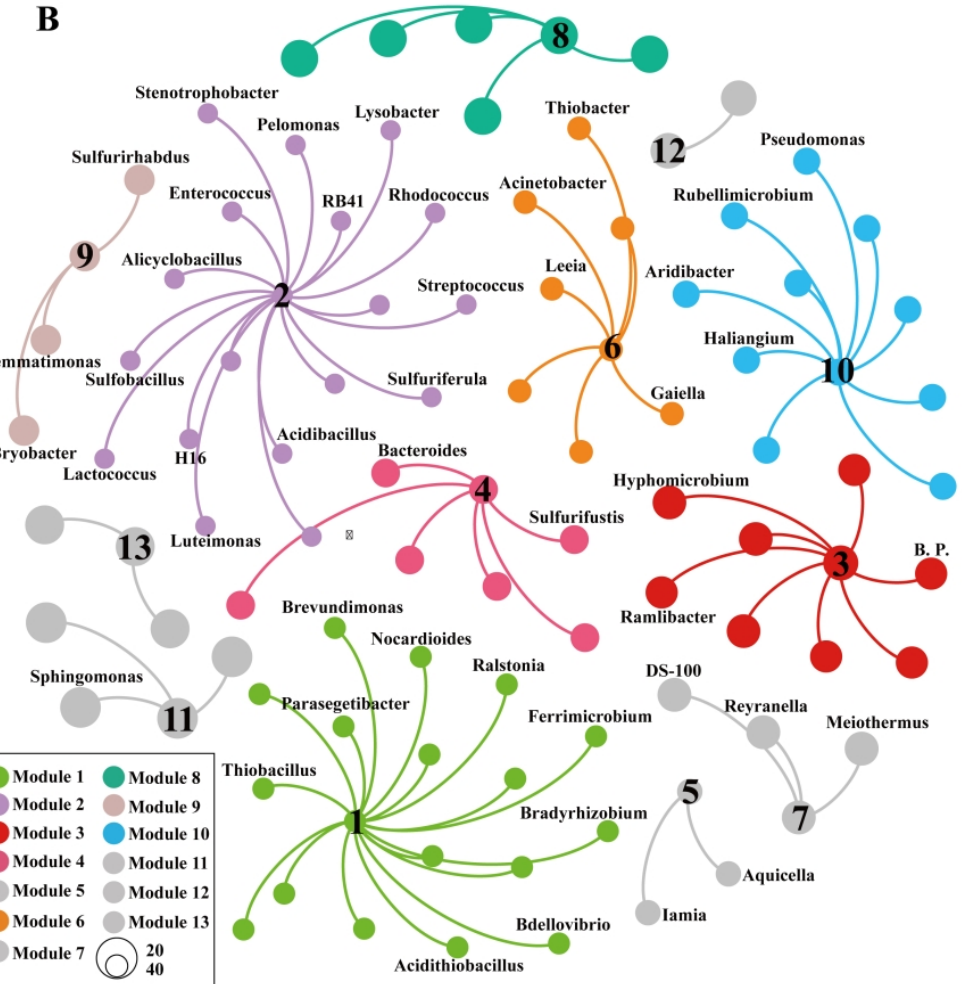

Fig. 4. (A) Network analysis for the detected bacterial communities (genus level) in different tailings sites. Color was coded by tailings sites. Each node indicates one genus. Colors of node represent the different major phyla. The size the species-node denotes abundance of species. Black nodes represented the no_rank/un-classified genera which were shared by tailings sites. Light green nodes represented the no_rank/unclassified genera, which were specific in different tailings sites. The degree of node was assessed by the numbers of nodes connected directly to that node. The more lines on the node denotes the higher degree of correlation between the sites and other genera. (B) The sub-network analysis for modularity of genera. Colors of node represent the different module. Node size is proportional to the modularity class. The nodes without labels represented the no_rank/un-classified genera. B. P., Burkholderia-Paraburkholderia 

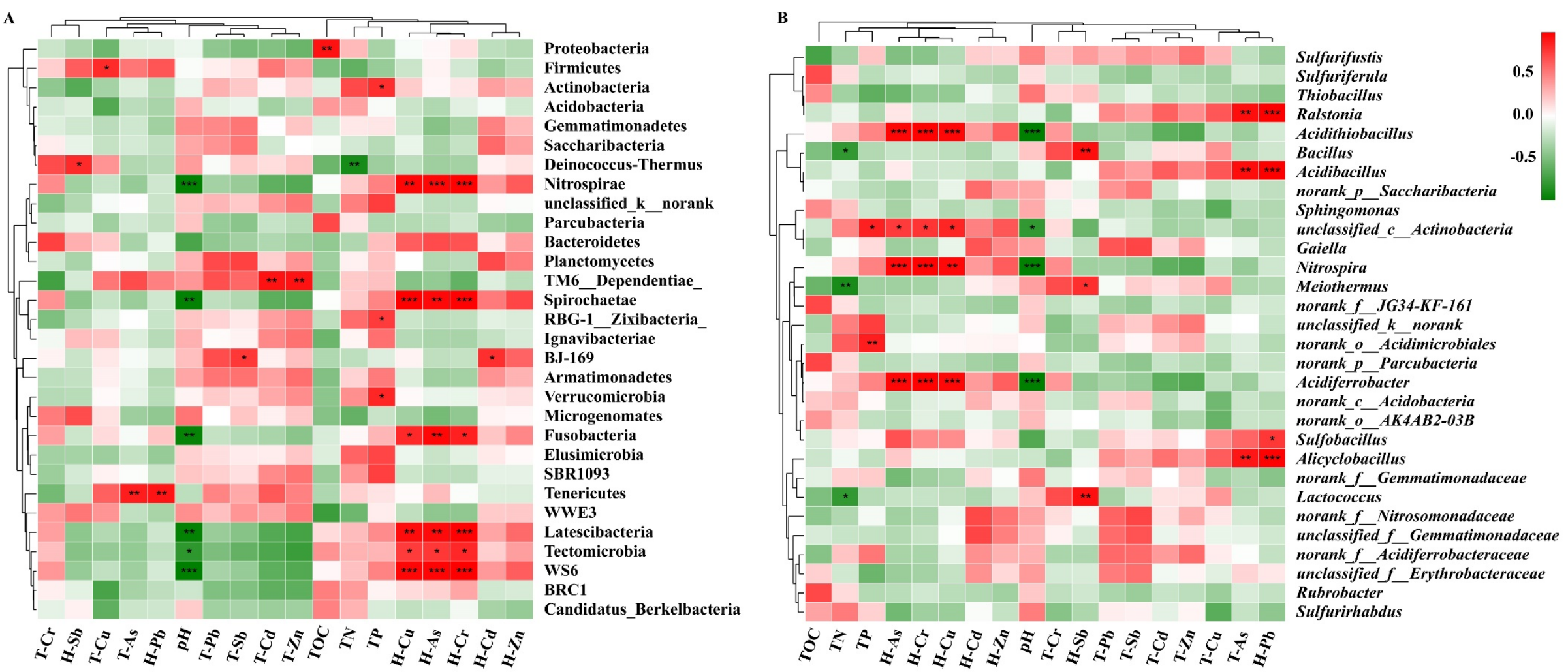

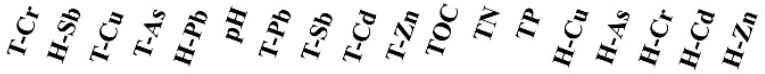

Fig. 5. Correlation analysis based on the Pearson test showing the relation between the geochemical factors and the relative abundance of bacterial communities at the phylum (A) and genus (B) levels. Only the top 30 bacterial communities are shown in this figure. Color key for the correlation values is shown on the right panel inset; positive correlations are in red text, negative correlations are in green, non-significant correlations are shown in white. $* 0.01<p \leq 0.05, * * 0.001<p \leq 0.01, * * * p \leq 0.001$ 


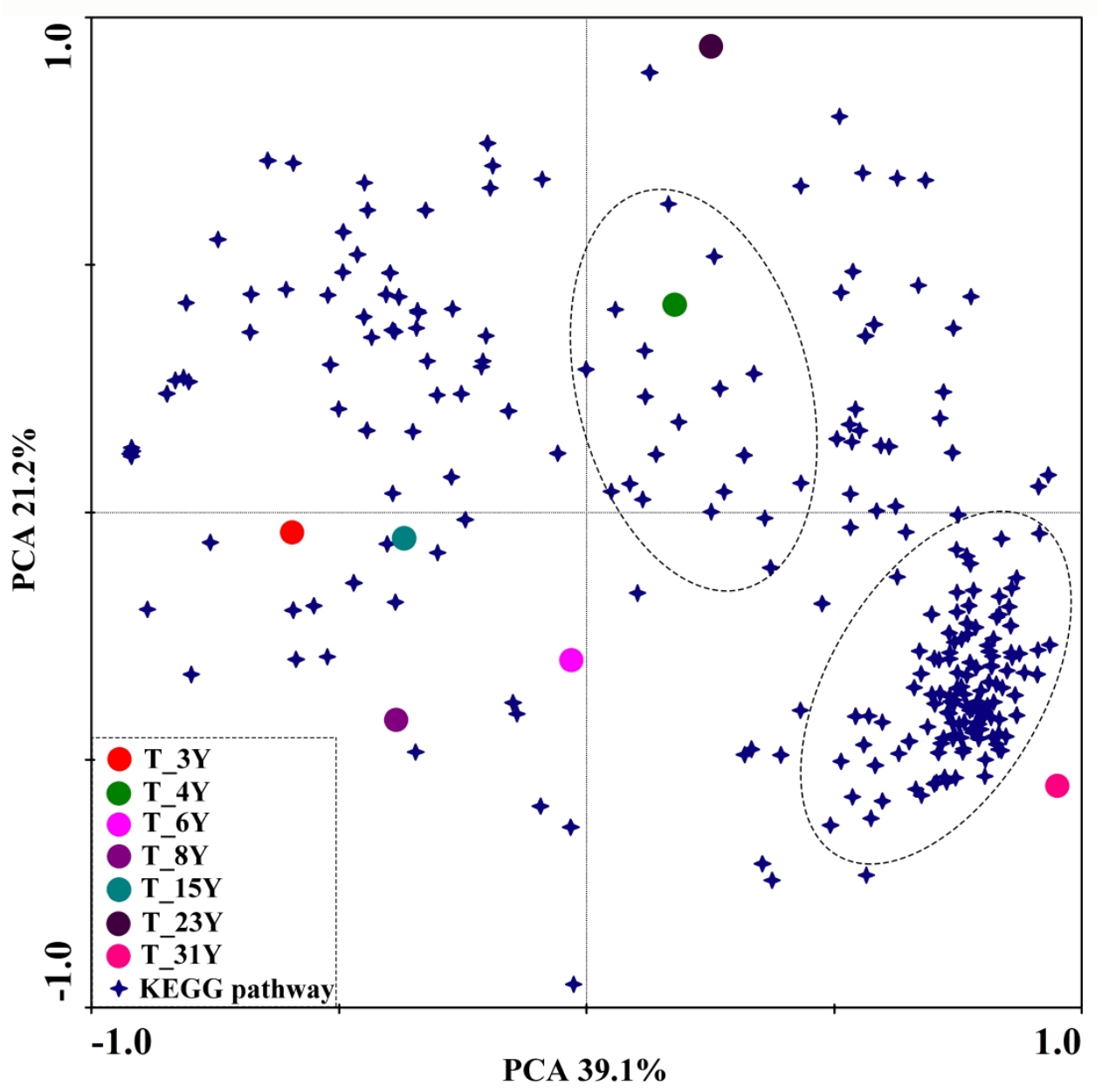

Fig. 6 Principal Components Analysis (PCA) for bacterial community structure and KEGG metabolic functional pathways based on 16S rRNA sequencing reads. 
Table 1

747 Spearman correlation analysis for geochemical factor variables and a-diversity index $748 \quad(p<0.05)$.

\begin{tabular}{|c|c|c|c|}
\hline $\begin{array}{l}\text { Variables used } \\
\text { in analysis }\end{array}$ & $\begin{array}{c}\text { Correlated variables } \\
|r h o|>0.75\end{array}$ & rho & $p$-value \\
\hline TOC & $\mathrm{H}-\mathrm{Cr}$ & $0.786^{*}$ & 0.036 \\
\hline \multirow[t]{3}{*}{$\mathrm{T}-\mathrm{As}$} & $\mathrm{T}-\mathrm{Cd}$ & $0.786^{*}$ & 0.036 \\
\hline & $\mathrm{T}-\mathrm{Cr}$ & $-0.821^{*}$ & 0.023 \\
\hline & $\mathrm{T}-\mathrm{Zn}$ & $0.857^{*}$ & 0.014 \\
\hline \multirow[t]{3}{*}{$\mathrm{T}-\mathrm{Cd}$} & $\mathrm{T}-\mathrm{Cu}$ & $0.786^{*}$ & 0.036 \\
\hline & $\mathrm{T}-\mathrm{Zn}$ & $0.929^{* *}$ & 0.003 \\
\hline & $\mathrm{H}-\mathrm{Cr}$ & $-0.893^{* *}$ & 0.007 \\
\hline \multirow[t]{2}{*}{$\mathrm{T}-\mathrm{Pb}$} & $\mathrm{H}-\mathrm{Cd}$ & $0.821^{*}$ & 0.023 \\
\hline & $\mathrm{H}-\mathrm{Pb}$ & $0.821^{*}$ & 0.023 \\
\hline $\mathrm{T}-\mathrm{Zn}$ & $\mathrm{H}-\mathrm{Cr}$ & $-0.893^{* *}$ & 0.007 \\
\hline \multirow[t]{2}{*}{$\mathrm{H}-\mathrm{Cd}$} & $\mathrm{H}-\mathrm{Cu}$ & $0.929^{* *}$ & 0.003 \\
\hline & $\mathrm{H}-\mathrm{Zn}$ & $0.929^{* *}$ & 0.003 \\
\hline $\mathrm{H}-\mathrm{Cu}$ & $\mathrm{H}-\mathrm{Zn}$ & $0.929^{* *}$ & 0.003 \\
\hline ace & PD & $0.964 * *$ & 0.0004 \\
\hline PD & $\mathrm{TP}$ & $-0.786^{*}$ & 0.036 \\
\hline
\end{tabular}
metal(loid)s; H-(metal), the acid extraction of metal(loid)s; ace, microbial richness; PD, 
753 Main genus contributed to the differences between different bacterial communities of 754 tailings sites with different abandoned time. The relative abundances of genera $\geq 1$ at 755 least at one tailing site are shown.

\begin{tabular}{|c|c|c|c|c|c|c|c|c|c|}
\hline \multirow{2}{*}{ Genus } & \multicolumn{9}{|c|}{ Contrib (\%) } \\
\hline & $\mathbf{a} \& \mathbf{b}$ & $\mathbf{a} \& \mathbf{c}$ & a \& d & a \& e & b \& c & b \& d & b \& e & $c \& d$ & c \& e \\
\hline Dissi & 68.3 & 68.4 & 59.2 & 73.5 & 52.7 & 56.9 & 83.2 & 49.6 & 78.5 \\
\hline Acidibacillus & - & - & - & 3.65 & - & - & 3.15 & - & 2.98 \\
\hline Acidiferrobacter & - & - & - & 2.52 & - & - & 2.17 & - & 2.06 \\
\hline Acidithiobacillus & - & - & - & 3.78 & - & - & 3.27 & - & 3.09 \\
\hline Acinetobacter & 0.93 & 0.69 & 0.75 & 0.97 & - & 0.70 & 1.56 & 0.73 & 1.37 \\
\hline Alicyclobacillus & - & - & - & 2.81 & - & - & 2.43 & - & 2.30 \\
\hline Bacillus & 7.34 & - & 0.67 & 0.40 & 8.17 & 7.89 & 5.36 & 0.71 & - \\
\hline Bdellovibrio & 2.37 & 1.81 & 2.18 & 2.47 & - & - & - & - & - \\
\hline Burkholderia- & - & - & - & 1.63 & - & - & 1.59 & - & 1.28 \\
\hline$D S-100$ & - & 1.59 & 1.34 & - & 2.04 & 1.38 & - & 1.04 & 1.37 \\
\hline Enterococcus & 1.51 & 0.96 & - & - & - & 1.87 & 1.14 & 1.43 & 0.76 \\
\hline Erysipelothrix & 3.04 & 2.70 & 3.33 & 1.96 & - & - & 0.68 & - & - \\
\hline Gaiella & - & 4.48 & 5.01 & - & 4.59 & 4.01 & 0.78 & 1.79 & 3.73 \\
\hline Gemmatimonas & 0.58 & - & 1.12 & 0.90 & 1.22 & 1.79 & - & 0.60 & 1.11 \\
\hline Iamia & 0.82 & 2.75 & 0.67 & - & 2.56 & - & 0.47 & 2.88 & 2.12 \\
\hline Lactococcus & 4.89 & - & - & - & 2.68 & 5.45 & 3.75 & - & - \\
\hline Meiothermus & 3.54 & 0.59 & 2.09 & 1.57 & 3.23 & 2.39 & 4.11 & 2.13 & 1.78 \\
\hline Nitrospira & 1.18 & 0.98 & - & 2.77 & - & 0.75 & 2.40 & 0.68 & 2.27 \\
\hline Ralstonia & 0.81 & - & - & - & - & - & 3.68 & - & 3.11 \\
\hline Rhodococcus & - & - & - & 1.35 & - & - & 1.29 & - & 1.22 \\
\hline Rubellimicrobium & - & - & 1.09 & 0.44 & - & - & - & - & - \\
\hline Rubrobacter & 3.91 & 2.66 & 3.16 & 3.54 & 1.02 & 1.13 & - & - & 0.68 \\
\hline Sphingomonas & - & 0.65 & 3.91 & 1.42 & 1.18 & - & 0.98 & - & 1.70 \\
\hline Sulfobacillus & - & - & - & 3.27 & - & - & 2.82 & - & 2.67 \\
\hline Sulfuriferula & 8.46 & 8.20 & 10.3 & 7.57 & - & 0.96 & 0.91 & - & 0.86 \\
\hline Sulfurifustis & 5.39 & 7.09 & 5.18 & 0.44 & 2.93 & 1.92 & 4.57 & 3.74 & 6.25 \\
\hline Sulfurirhabdus & 1.69 & 1.12 & 1.11 & 1.53 & - & 3.01 & - & - & - \\
\hline Thermithiobacillus & 2.84 & 2.52 & 3.11 & 2.56 & - & - & - & - & - \\
\hline Thiobacillus & 1.97 & 3.53 & 0.65 & 5.07 & 2.27 & 1.53 & 2.84 & 3.87 & 1.20 \\
\hline Thiobacter & - & 2.40 & - & - & 2.46 & - & 0.41 & 2.59 & 2.00 \\
\hline
\end{tabular}

Contrib, the contribution of each genus to the differences of bacterial communities of tailings sites;

757 a, T_3Y; b, T_4Y; c, T_6Y; d, T_8Y and T_15Y; e, T_23Y and T_31Y; “-”, the contribution data $758<0.4$. 
Table 3

760 Correlation analysis of modules eigengenes in the bacterial community network (Fig.

761 4) and selected geochemical factors by BIOENV analysis and Monte-Carlo test.

\begin{tabular}{llccc}
\hline Combination of geochemical factors & & Module 1 & Module 2 & Module 3 \\
\hline $\mathrm{T}-\mathrm{As}$ & $\mathrm{rM}$ & 0.51 & 0.29 & 0.54 \\
& $p$ & 0.07 & 0.28 & 0.10 \\
$\mathrm{TOC}+\mathrm{H}-\mathrm{Pb}$ & $\mathrm{rM}$ & 0.32 & 0.58 & 0.59 \\
& $p$ & 0.20 & 0.03 & 0.07 \\
$\mathrm{pH}+\mathrm{TOC}+\mathrm{H}-\mathrm{Pb}$ & $\mathrm{rM}$ & 0.84 & 0.33 & 0.26 \\
& $p$ & 0.01 & 0.11 & 0.19 \\
$\mathrm{TOC}+\mathrm{H}-\mathrm{Pb}+\mathrm{T}-\mathrm{As}$ & $\mathrm{rM}$ & 0.37 & 0.53 & 0.62 \\
& $p$ & 0.16 & 0.06 & 0.08 \\
$\mathrm{pH}+\mathrm{TOC}+\mathrm{H}-\mathrm{Pb}+\mathrm{T}-\mathrm{As}$ & $\mathrm{rM}$ & 0.80 & 0.37 & 0.48 \\
& $p$ & 0.01 & 0.10 & 0.13 \\
$\mathrm{TOC}+\mathrm{H}-\mathrm{Pb}+\mathrm{T}-\mathrm{As}+\mathrm{H}-\mathrm{Sb}$ & $\mathrm{rM}$ & 0.27 & 0.69 & 0.51 \\
& $p$ & 0.23 & 0.08 & 0.13 \\
\hline
\end{tabular}




\title{
Supporting Information
}

\section{Bacterial diversity in typical abandoned multi-contaminated nonferrous metal(loid) tailings during natural attenuation}

\author{
Jian-li Liu a, Jun Yao ${ }^{\text {** }}$, Fei Wang a, Ning Min”, Ji-hai Gu ${ }^{\text {a }}, \mathrm{Zi}-\mathrm{fu} \mathrm{Li}^{\text {a }}{ }^{\text {** }}$, \\ Geoffrey Sunahara ${ }^{c}$, Robert Duran ${ }^{\mathrm{d}}$, Tatjana Solevic Knudsen ${ }^{\mathrm{e}}$, \\ Karen A. Hudson-Edwards ${ }^{g}$ and Lena Alakangas ${ }^{\mathrm{h}}$
}

a School of Energy and Environment Engineering, University of Science and Technology Beijing, Beijing 100083, China

${ }^{\mathrm{b}}$ School of Water Resource and Environment Engineering, China University of Geosciences (Beijing) 100083, China

${ }^{c}$ Department of Natural Resource Sciences, McGill University, Montreal, Quebec, H9X3V9, Canada

${ }^{\mathrm{d}}$ Equipe Environnement et Microbiologie, MELODY group, Université de Pau et des Pays de l'Adour, E2S-UPPA, IPREM UMR CNRS 5254, BP 1155, 64013 Pau Cedex, France

${ }^{\mathrm{e}}$ Institute of Chemistry, Technology and Metallurgy, University of Belgrade, Njegoseva 12, PO Box 473, 11001 Belgrade, Serbia

${ }_{\mathrm{f}}^{\mathrm{f}}$ Department of Applied Chemistry, Szent István University, Villányi út 35-43, 1118 Budapest, Hungary

g Environment \& Sustainability Institute and Camborne School of Mines, University of Exeter, Penryn, Cornwall TR10 9DF, UK

${ }^{\mathrm{h}}$ Lule University of Technology, -971 87 Lule1, Sweden

\section{Submitted to: Environment Pollution}

Supplementary Tables: 7

Supplementary Figures: 1

* Corresponding Author. School of Water Resource and Environmental Engineering, China University of Geosciences (Beijing), 29 Xueyuan Road, Haidian District, 100083 Beijing, China, E-mail: yaojun@cugb.edu.cn (J. Yao), Tel: +86-10-82321958

** Corresponding Author. School of Energy \& Environmental Engineering, University of Science and Technology Beijing, 30 Xueyuan Road, Haidian District,100083 Beijing, China, E-mail: zifulee@aliyun.com (Z.F. Li), Tel: +86-10-62334378 
Types of tail sand for mining and smelting industries and geochemical factors of the studied tailings sites.

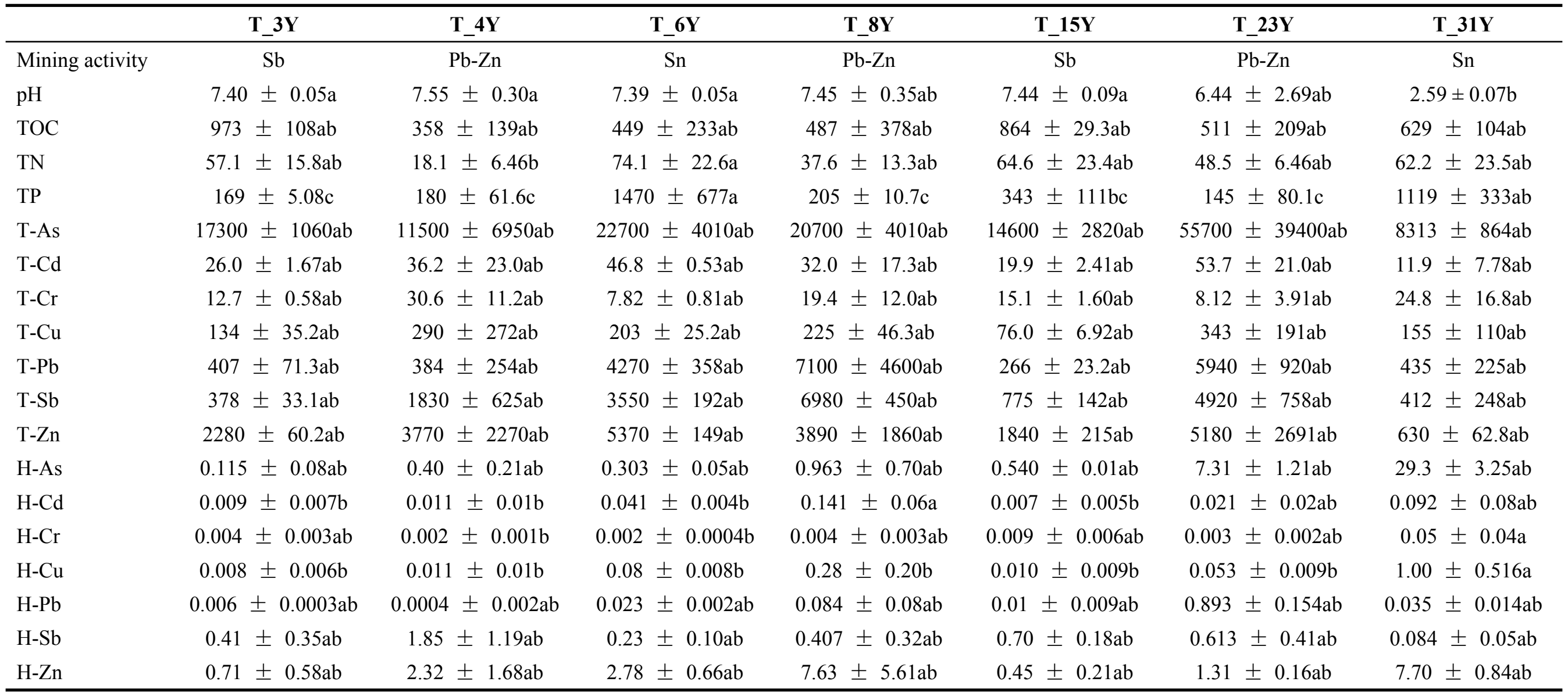

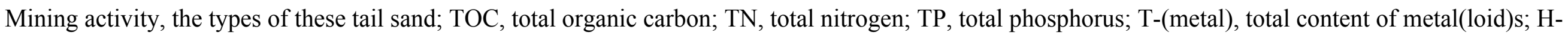

(metal), the acid leachable metal(loid)s. The unit for TOC, TN, TP, and content of metal(loid)s is mg/kg. Different letters in the same row denote significant

differences between tailings sites at $p<0.05$ level. "-" = no data. 
$40 \quad$ Table S2.

41 The average sequences data for 16S rRNA in each tailing site.

\begin{tabular}{cccccccc}
\hline Sample ID & Seq_num & Mean_lengt & Shannon & ace & coverage & PD & NSTI \\
\hline T_3Y & 36309 & 440 & 2.88 & 601 & 0.998 & 45.5 & 0.34 \\
T_4Y & 41493 & 444 & 3.67 & 621 & 0.999 & 51.2 & 0.12 \\
T_6Y & 44161 & 438 & 4.67 & 678 & 0.999 & 58.6 & 0.18 \\
T_8Y & 37562 & 439 & 4.43 & 571 & 0.997 & 43.7 & 0.17 \\
T_15Y & 37001 & 438 & 4.80 & 598 & 0.999 & 47.7 & 0.17 \\
T_23Y & 33465 & 445 & 3.12 & 255 & 0.997 & 25.9 & 0.07 \\
T_31Y & 35496 & 445 & 3.37 & 794 & 0.998 & 60.8 & 0.18 \\
\hline
\end{tabular}

42 Seq_num, the sequences number for each tailing site; Mean_length, the average length of 43 sequences; NSTI, nearest sequenced taxon index. Four $\alpha$-diversity indices (Shannon, ace, $44 \mathrm{PD}$, and coverage) are shown to estimate bacterial community diversity, richness, 45 phylogenetic diversity, and community coverage. The analysis for bacterial communities in 46 seven tailings sites at OTU level were based on 97\% similarity. Data points for T_3Y, 47 T_4Y, T_6Y, T_8Y, T_15Y, T_23Y, and T_31Y represent tailings sites having 3, 4, 6, 8, 4815,23 , and 31 years of abandonment, respectively. 
$49 \quad$ Table S3.

50 Average OTU distribution for 16S rDNA sequences in each tailing site. T_3Y, T_4Y,

51 T_6Y, T_8Y, T_15Y, T_23Y and T_31Y represent different tailing sites with different ages

52 of abandonment. The table has been listed as a separate worksheet file. 
$53 \quad$ Table S4.

54 Relative abundance (\%) of genera in the seven studied tailing sites. Only genera with

55 relative abundance $>1 \%$ in at least one tailing samples are shown.

\begin{tabular}{lccccccc}
\hline Genus & T_3Y & T_4Y & T_6Y & T_8Y & T_15Y & T_23Y & T_31Y \\
\hline Acidibacillus & 0.00 & 0.00 & 0.00 & 0.00 & 0.00 & 23.9 & 0.40 \\
Acidiferrobacter & 0.00 & 0.00 & 0.00 & 0.00 & 0.00 & 0.00 & 12.5 \\
Acidithiobacillus & 0.00 & 0.00 & 0.00 & 0.00 & 0.00 & 0.00 & 28.3 \\
Acinetobacter & 0.40 & 0.00 & 0.00 & 0.00 & 0.40 & 0.34 & 1.10 \\
Alicyclobacillus & 0.00 & 0.00 & 0.00 & 0.00 & 0.00 & 9.10 & 1.30 \\
Bacillus & 0.10 & 25.0 & 0.10 & 0.00 & 0.50 & 0.80 & 0.20 \\
Bdellovibrio & 2.70 & 0.10 & 0.10 & 0.10 & 0.30 & 0.00 & 0.00 \\
Brevundimonas & 0.10 & 0.00 & 0.00 & 0.10 & 0.40 & 1.30 & 0.00 \\
Burkholderia-Paraburkholderia & 0.00 & 0.00 & 0.00 & 0.00 & 0.10 & 5.10 & 0.30 \\
DS-100 & 0.00 & 0.00 & 0.80 & 0.10 & 1.20 & 0.00 & 0.00 \\
Enterococcus & 0.00 & 1.10 & 0.30 & 0.00 & 0.00 & 0.00 & 0.00 \\
Erysipelothrix & 3.10 & 0.00 & 0.00 & 0.00 & 0.00 & 0.00 & 1.20 \\
Gaiella & 0.10 & 0.90 & 6.30 & 10.5 & 2.50 & 0.10 & 0.10 \\
Gemmatimonas & 0.30 & 0.10 & 0.50 & 1.30 & 0.70 & 0.00 & 0.00 \\
Iamia & 0.00 & 0.30 & 2.00 & 0.10 & 0.10 & 0.00 & 0.00 \\
Lactococcus & 0.00 & 9.60 & 0.00 & 0.00 & 0.00 & 0.00 & 0.00 \\
Luteimonas & 0.00 & 0.00 & 0.00 & 0.00 & 3.10 & 0.00 & 0.00 \\
Meiothermus & 1.00 & 11.2 & 1.20 & 5.70 & 0.30 & 0.00 & 0.00 \\
Nitrospira & 0.10 & 1.20 & 0.60 & 0.40 & 0.10 & 0.10 & 17.2 \\
Ralstonia & 0.20 & 0.00 & 0.10 & 0.30 & 0.20 & 28.8 & 1.10 \\
Rhodococcus & 0.10 & 0.00 & 0.00 & 0.00 & 0.00 & 4.70 & 0.00 \\
Rubellimicrobium & 0.10 & 0.10 & 0.10 & 0.20 & 1.10 & 0.00 & 0.00 \\
Rubrobacter & 5.60 & 0.00 & 0.20 & 0.30 & 0.30 & 0.00 & 0.00 \\
Sphingomonas & 1.40 & 1.20 & 1.60 & 3.50 & 13.1 & 0.00 & 0.20 \\
Sulfobacillus & 0.00 & 0.00 & 0.00 & 0.00 & 0.00 & 6.70 & 4.80 \\
Sulfuriferula & 31.0 & 0.50 & 0.00 & 0.00 & 0.00 & 0.00 & 2.20 \\
Sulfurifustis & 0.10 & 13.9 & 14.7 & 11.5 & 2.40 & 0.00 & 0.00 \\
Sulfurirhabdus & 1.00 & 0.00 & 1.80 & 1.30 & 2.20 & 0.00 & 0.00 \\
Thermithiobacillus & 2.70 & 0.00 & 0.00 & 0.00 & 0.00 & 0.00 & 0.00 \\
Thiobacillus & 11.6 & 6.10 & 0.70 & 8.10 & 4.90 & 0.10 & 0.00 \\
Thiobacter & 0.00 & 0.10 & 1.50 & 0.10 & 0.00 & 0.00 & 0.00 \\
\hline & & & & & & &
\end{tabular}


Table S5.

58 Relative abundance (\%) of predicted KEGG pathways at studied tailing sites, based on 16S rRNA sequencing. The top fifty metabolic 59 pathways of KEGG subsytems (at level 3) are shown.

\begin{tabular}{|c|c|c|c|c|c|c|c|c|}
\hline Metabolism pathway on level 1 & Metabolism pathway on level 3 & T_3Y & T_4Y & T_6Y & T_8Y & T_15Y & T_23Y & T_31Y \\
\hline \multirow[t]{2}{*}{ Cellular Processes } & Bacterial motility proteins & 0.01 & 0.02 & 0.02 & 0.02 & 0.02 & 0.02 & 0.02 \\
\hline & Flagellar assembly & 0.01 & 0.01 & 0.01 & 0.01 & 0.01 & 0.01 & 0.01 \\
\hline \multirow{6}{*}{$\begin{array}{l}\text { Environmental Information } \\
\text { Processing }\end{array}$} & Transporters & 0.03 & 0.06 & 0.05 & 0.05 & 0.04 & 0.05 & 0.04 \\
\hline & $\mathrm{ABC}$ transporters & 0.02 & 0.03 & 0.03 & 0.03 & 0.03 & 0.03 & 0.02 \\
\hline & Two-component system & 0.01 & 0.02 & 0.02 & 0.02 & 0.02 & 0.02 & 0.02 \\
\hline & Secretion system & 0.01 & 0.02 & 0.02 & 0.02 & 0.02 & 0.02 & 0.02 \\
\hline & Other ion-coupled transporters & 0.01 & 0.01 & 0.01 & 0.01 & 0.01 & 0.01 & 0.01 \\
\hline & Bacterial secretion system & 0.01 & 0.01 & 0.01 & 0.01 & 0.01 & 0.01 & 0.01 \\
\hline \multirow[t]{13}{*}{ Genetic Information Processing } & DNA repair and recombination proteins & 0.02 & 0.03 & 0.03 & 0.02 & 0.02 & 0.02 & 0.03 \\
\hline & Ribosome & 0.01 & 0.02 & 0.02 & 0.02 & 0.02 & 0.02 & 0.02 \\
\hline & Chromosome & 0.01 & 0.02 & 0.01 & 0.01 & 0.01 & 0.01 & 0.02 \\
\hline & Transcription factors & 0.01 & 0.01 & 0.01 & 0.01 & 0.01 & 0.02 & 0.01 \\
\hline & Ribosome Biogenesis & 0.01 & 0.01 & 0.01 & 0.01 & 0.01 & 0.01 & 0.01 \\
\hline & Aminoacyl-tRNA biosynthesis & 0.01 & 0.01 & 0.01 & 0.01 & 0.01 & 0.01 & 0.01 \\
\hline & Chaperones and folding catalysts & 0.01 & 0.01 & 0.01 & 0.01 & 0.01 & 0.01 & 0.01 \\
\hline & Transcription machinery & 0.01 & 0.01 & 0.01 & 0.01 & 0.01 & 0.01 & 0.01 \\
\hline & DNA replication proteins & 0.01 & 0.01 & 0.01 & 0.01 & 0.01 & 0.01 & 0.01 \\
\hline & Protein folding and associated processing & 0.01 & 0.01 & 0.01 & 0.01 & 0.01 & 0.01 & 0.01 \\
\hline & Translation proteins & 0.01 & 0.01 & 0.01 & 0.01 & 0.01 & 0.01 & 0.01 \\
\hline & Homologous recombination & 0.01 & 0.01 & 0.01 & 0.01 & 0.01 & 0.01 & 0.01 \\
\hline & Replication, recombination and repair proteins & 0.01 & 0.01 & 0.01 & 0.01 & 0.01 & 0.01 & 0.01 \\
\hline metabolism & Purine metabolism & 0.01 & 0.02 & 0.02 & 0.02 & 0.02 & 0.02 & 0.02 \\
\hline
\end{tabular}


Oxidative phosphorylation

Peptidases

Pyrimidine metabolism

Amino acid related enzymes

Arginine and proline metabolism

Pyruvate metabolism

Methane metabolism

Butanoate metabolism

Carbon fixation pathways in prokaryotes

Glycolysis / Gluconeogenesis

Propanoate metabolism

Amino sugar and nucleotide sugar metabolism

Porphyrin and chlorophyll metabolism

Alanine, aspartate and glutamate metabolism

Valine, leucine and isoleucine degradation

Citrate cycle (TCA cycle)

Lipid biosynthesis proteins

Glycine, serine and threonine metabolism

Energy metabolism

Fatty acid metabolism

Glyoxylate and dicarboxylate metabolism

Cysteine and methionine metabolism

Valine, leucine and isoleucine biosynthesis

Nitrogen metabolism

Phenylalanine, tyrosine and tryptophan biosynthesis

Peptidoglycan biosynthesis

Poorly characterized

General function prediction only

Function unknown

\begin{tabular}{lllllll}
0.01 & 0.02 & 0.02 & 0.02 & 0.02 & 0.01 & 0.02 \\
0.01 & 0.02 & 0.01 & 0.01 & 0.02 & 0.02 & 0.02 \\
0.01 & 0.02 & 0.01 & 0.01 & 0.01 & 0.01 & 0.01 \\
0.01 & 0.01 & 0.01 & 0.01 & 0.01 & 0.01 & 0.01 \\
0.01 & 0.01 & 0.01 & 0.01 & 0.01 & 0.01 & 0.01 \\
0.01 & 0.01 & 0.01 & 0.01 & 0.01 & 0.01 & 0.01 \\
0.01 & 0.01 & 0.01 & 0.01 & 0.01 & 0.01 & 0.01 \\
0.01 & 0.01 & 0.01 & 0.01 & 0.01 & 0.01 & 0.01 \\
0.01 & 0.01 & 0.01 & 0.01 & 0.01 & 0.01 & 0.01 \\
0.01 & 0.01 & 0.01 & 0.01 & 0.01 & 0.01 & 0.01 \\
0.01 & 0.01 & 0.01 & 0.01 & 0.01 & 0.01 & 0.01 \\
0.01 & 0.01 & 0.01 & 0.01 & 0.01 & 0.01 & 0.01 \\
0.01 & 0.01 & 0.01 & 0.01 & 0.01 & 0.01 & 0.01 \\
0.01 & 0.01 & 0.01 & 0.01 & 0.01 & 0.01 & 0.01 \\
0.01 & 0.01 & 0.01 & 0.01 & 0.01 & 0.01 & 0.00 \\
0.01 & 0.01 & 0.01 & 0.01 & 0.01 & 0.01 & 0.01 \\
0.01 & 0.01 & 0.01 & 0.01 & 0.01 & 0.01 & 0.01 \\
0.01 & 0.01 & 0.01 & 0.01 & 0.01 & 0.01 & 0.01 \\
0.01 & 0.01 & 0.01 & 0.01 & 0.01 & 0.01 & 0.01 \\
0.01 & 0.01 & 0.01 & 0.01 & 0.01 & 0.01 & 0.00 \\
0.01 & 0.01 & 0.01 & 0.01 & 0.01 & 0.01 & 0.01 \\
0.01 & 0.01 & 0.01 & 0.01 & 0.01 & 0.01 & 0.01 \\
0.01 & 0.01 & 0.01 & 0.01 & 0.01 & 0.01 & 0.01 \\
0.01 & 0.01 & 0.01 & 0.01 & 0.01 & 0.01 & 0.01 \\
0.01 & 0.01 & 0.01 & 0.01 & 0.01 & 0.01 & 0.01 \\
0.01 & 0.01 & 0.01 & 0.01 & 0.01 & 0.01 & 0.01 \\
0.02 & 0.04 & 0.04 & 0.04 & 0.03 & 0.03 & 0.03 \\
0.01 & 0.02 & 0.02 & 0.02 & 0.02 & 0.02 & 0.02 \\
0.56 & 0.35 & 0.36 & 0.36 & 0.37 & 0.37 & 0.36 \\
\hline & & & & & &
\end{tabular}


Main KEGG pathways contributed to the differences between different metabolic pathways of tailings sites. The top fifty metabolic pathways of KEGG subsytems (at level 3) are shown.

\begin{tabular}{|c|c|c|c|c|c|c|c|c|c|c|c|c|c|c|c|c|}
\hline $\begin{array}{l}\text { Metabolism pathway } \\
\text { on level } 1\end{array}$ & Metabolism pathway on level 3 & b\&c & b\& & b\&e & $\mathbf{b \& f}$ & $\mathbf{b \&}$ & d\&e & $\begin{array}{r}\mathbf{d} \& \mathbf{f} \\
C\end{array}$ & $\begin{array}{c}\mathbf{d \&} \\
\text { ntrib }(\mathrm{C}\end{array}$ & d\&c & e\&f & e\&a & e\&c & f\&a & f\&c & $\overline{a \& c}$ \\
\hline \multirow[t]{2}{*}{ Cellular Processes } & Bacterial motility proteins & - & - & - & - & - & - & - & - & - & - & 0.6 & - & - & - & 0.49 \\
\hline & Flagellar assembly & - & - & - & - & - & - & - & - & - & - & - & - & - & - & - \\
\hline \multirow{6}{*}{$\begin{array}{l}\text { Environmental } \\
\text { Information Processing }\end{array}$} & Transporters & 1.21 & 2.00 & 1.00 & 1.05 & 0.60 & - & - & - & - & - & - & - & - & - & - \\
\hline & $\mathrm{ABC}$ transporters & 1.26 & 1.7 & 1.2 & 1.12 & - & - & - & - & - & - & - & - & - & - & - \\
\hline & Two-component system & - & - & - & - & 0.60 & - & - & 0.58 & - & - & - & - & - & - & - \\
\hline & Secretion system & - & - & - & - & - & - & - & 0.61 & - & - & 0.72 & - & 0.50 & - & 0.48 \\
\hline & Other ion-coupled transporters & - & - & - & - & - & - & - & - & - & - & - & - & - & - & - \\
\hline & Bacterial secretion system & - & - & - & - & 0.50 & - & - & 0.63 & - & - & 0.71 & - & 0.50 & - & 0.51 \\
\hline \multirow{12}{*}{$\begin{array}{l}\text { Genetic Information } \\
\text { Processing }\end{array}$} & DNA repair and recombination proteins & - & - & - & - & 0.60 & - & - & 0.52 & - & - & 0.61 & - & 0.50 & - & 0.52 \\
\hline & Ribosome & - & - & - & - & - & - & - & - & - & - & - & - & 0.50 & - & - \\
\hline & Chromosome & - & - & - & - & 0.60 & - & - & - & - & - & 0.68 & - & 0.50 & - & - \\
\hline & Ribosome Biogenesis & - & - & - & - & - & - & - & - & - & - & - & - & - & - & - \\
\hline & Aminoacyl-tRNA biosynthesis & - & - & - & - & - & - & - & 0.52 & - & - & 0.62 & - & - & - & - \\
\hline & Chaperones and folding catalysts & - & - & - & - & - & - & - & - & - & - & - & - & - & - & - \\
\hline & Transcription machinery & - & - & 0.50 & 0.71 & 0.60 & - & - & 0.57 & - & - & - & - & - & - & - \\
\hline & DNA replication proteins & - & - & - & - & - & - & - & 0.54 & - & - & 0.68 & - & 0.60 & - & 0.55 \\
\hline & Protein folding and associated processing & - & - & - & - & - & - & - & - & - & - & - & - & 0.60 & - & 0.54 \\
\hline & Translation proteins & - & 0.60 & - & - & 0.60 & - & - & - & - & - & 0.60 & - & - & - & - \\
\hline & Homologous recombination & - & - & - & - & - & - & - & - & - & - & - & - & - & - & - \\
\hline & Replication, recombination and repair proteins & - & - & - & - & - & - & - & - & - & - & - & - & - & - & - \\
\hline
\end{tabular}




\begin{tabular}{|c|c|c|c|c|c|c|c|c|c|c|c|c|c|c|c|c|}
\hline \multirow[t]{27}{*}{ Mtabolism } & Purine metabolism & - & - & - & - & 0.70 & - & - & - & - & - & - & - & - & - & - \\
\hline & Oxidative phosphorylation & - & - & - & - & 0.60 & - & - & 0.62 & - & - & - & - & 0.50 & - & - \\
\hline & Peptidases & - & - & - & - & 0.70 & - & - & - & - & - & - & - & - & - & - \\
\hline & Pyrimidine metabolism & - & 0.50 & - & - & 0.70 & - & - & - & - & - & - & - & - & - & - \\
\hline & Amino acid related enzymes & - & - & - & - & 0.70 & - & - & - & - & - & 0.62 & - & - & - & - \\
\hline & Arginine and proline metabolism & - & 0.70 & - & 0.88 & - & - & - & - & - & - & - & - & - & - & - \\
\hline & Pyruvate metabolism & - & - & - & - & 0.70 & - & - & - & - & - & - & - & - & - & - \\
\hline & Methane metabolism & - & - & - & - & 0.60 & - & - & 0.62 & - & - & 0.57 & - & 0.60 & - & 0.55 \\
\hline & Butanoate metabolism & 1.22 & - & - & - & - & - & - & - & - & - & - & - & - & - & - \\
\hline & Carbon fixation pathways in prokaryotes & - & - & - & - & 0.70 & - & - & - & - & - & - & - & - & - & - \\
\hline & Glycolysis / Gluconeogenesis & - & - & - & - & 0.70 & - & - & - & - & - & 0.58 & - & - & - & - \\
\hline & Propanoate metabolism & - & - & - & 0.89 & - & - & - & - & - & - & - & - & - & - & - \\
\hline & Amino sugar and nucleotide sugar metabolism & - & - & - & - & - & - & - & 0.48 & - & - & 0.54 & - & 0.40 & - & - \\
\hline & Porphyrin and chlorophyll metabolism & - & - & - & 0.38 & - & - & - & - & - & - & - & - & - & - & - \\
\hline & Alanine, aspartate and glutamate metabolism & - & 0.60 & - & 0.72 & - & - & - & - & - & - & - & - & - & - & - \\
\hline & Valine, leucine and isoleucine degradation & - & - & - & - & - & - & - & - & - & - & - & - & - & - & - \\
\hline & Citrate cycle (TCA cycle) & - & - & - & - & - & - & - & - & - & - & - & - & - & - & - \\
\hline & Lipid biosynthesis proteins & - & - & - & - & - & - & - & - & - & - & - & - & - & - & - \\
\hline & Glycine, serine and threonine metabolism & 1.01 & - & - & 0.74 & - & - & - & - & - & - & - & - & - & - & - \\
\hline & Energy metabolism & - & - & - & 0.88 & - & - & - & - & - & - & - & - & - & - & - \\
\hline & Fatty acid metabolism & 1.37 & - & - & - & - & - & - & - & - & - & - & - & - & - & - \\
\hline & Glyoxylate and dicarboxylate metabolism & - & - & - & - & 0.60 & - & - & - & - & - & 0.61 & - & 0.50 & - & - \\
\hline & Cysteine and methionine metabolism & - & - & - & - & 0.60 & - & - & - & - & - & - & - & - & - & - \\
\hline & Valine, leucine and isoleucine biosynthesis & 0.99 & - & - & 0.59 & - & - & 0.74 & - & 1.24 & - & - & - & - & - & 0.48 \\
\hline & Nitrogen metabolism & - & - & - & - & 0.60 & - & - & 0.60 & - & - & 0.66 & - & 0.50 & - & 0.48 \\
\hline & Phenylalanine, tyrosine and tryptophan & - & - & - & - & 0.60 & - & - & 0.60 & - & - & - & - & - & - & - \\
\hline & Peptidoglycan biosynthesis & - & - & - & - & - & - & - & 0.57 & - & - & - & - & - & - & 0.54 \\
\hline \multirow[t]{2}{*}{ Poorly Characterized } & General function prediction only & - & - & - & - & - & - & - & - & - & - & 0.63 & - & - & - & - \\
\hline & Function unknown & - & 0.60 & - & 0.60 & 0.70 & - & - & - & - & - & - & - & - & - & - \\
\hline
\end{tabular}


BIOENV analysis for the relationships between geochemical variables and functional prediction of KEGG pathways.

\begin{tabular}{ll}
\hline Combination of geochemical factors & $r$ \\
\hline $\mathrm{H}-\mathrm{Cr}$ & 0.796 \\
$\mathrm{~T}-\mathrm{Zn}+\mathrm{H}-\mathrm{Cr}$ & 0.846 \\
$\mathrm{pH}+\mathrm{TP}+\mathrm{T}-\mathrm{Zn}$ & 0.900 \\
$\mathrm{pH}+\mathrm{TOC}+\mathrm{TP}+\mathrm{T}-\mathrm{Cd}$ & 0.943 \\
$\mathrm{pH}+\mathrm{TOC}+\mathrm{TP}+\mathrm{T}-\mathrm{As}+\mathrm{H}-\mathrm{Cr}$ & 0.957 \\
$\mathrm{pH}+\mathrm{TOC}+\mathrm{TP}+\mathrm{T}-\mathrm{As}+\mathrm{T}-\mathrm{Zn}+\mathrm{H}-\mathrm{Cr}$ & 0.979 \\
$\mathrm{pH}+\mathrm{TOC}+\mathrm{TP}+\mathrm{T}-\mathrm{As}+\mathrm{T}-\mathrm{Zn}+\mathrm{H}-\mathrm{Cr}+\mathrm{H}-\mathrm{Cu}$ & 0.975 \\
$\mathrm{pH}+\mathrm{TOC}+\mathrm{TP}+\mathrm{T}-\mathrm{As}+\mathrm{T}-\mathrm{Zn}+\mathrm{H}-\mathrm{As}+\mathrm{H}-\mathrm{Cr}+\mathrm{H}-\mathrm{Cu}$ & 0.964 \\
$\mathrm{pH}+\mathrm{TOC}+\mathrm{TN}+\mathrm{TP}+\mathrm{T}-\mathrm{Cd}+\mathrm{T}-\mathrm{Zn}+\mathrm{H}-\mathrm{Cr}+\mathrm{H}-\mathrm{Cu}+\mathrm{H}-\mathrm{Pb}$ & 0.946 \\
$\mathrm{pH}+\mathrm{TOC}+\mathrm{TN}+\mathrm{TP}+\mathrm{T}-\mathrm{Cd}+\mathrm{T}-\mathrm{Zn}+\mathrm{H}-\mathrm{As}+\mathrm{H}-\mathrm{Cr}+\mathrm{H}-\mathrm{Cu}+\mathrm{H}-\mathrm{Pb}$ & 0.943 \\
$\mathrm{pH}+\mathrm{TOC}+\mathrm{TP}+\mathrm{T}-\mathrm{Cd}+\mathrm{T}-\mathrm{Cr}+\mathrm{T}-\mathrm{Cu}+\mathrm{T}-\mathrm{Zn}+\mathrm{H}-\mathrm{As}+\mathrm{H}-\mathrm{Cr}+\mathrm{H}-\mathrm{Cu}+\mathrm{H}-\mathrm{Pb}$ \\
$\mathrm{pH}+\mathrm{TOC}+\mathrm{TN}+\mathrm{TP}+\mathrm{T}-\mathrm{As}+\mathrm{T}-\mathrm{Cd}+\mathrm{T}-\mathrm{Sb}+\mathrm{T}-\mathrm{Zn}+\mathrm{H}-\mathrm{As}+\mathrm{H}-\mathrm{Cr}+\mathrm{H}-\mathrm{Cu}+\mathrm{H}-\mathrm{Pb}$ \\
$\mathrm{pH}+\mathrm{TOC}+\mathrm{TN}+\mathrm{TP}+\mathrm{T}-\mathrm{As}+\mathrm{T}-\mathrm{Cd}+\mathrm{T}-\mathrm{Cu}+\mathrm{T}-\mathrm{Zn}+\mathrm{H}-\mathrm{As}+\mathrm{H}-\mathrm{Cr}+\mathrm{H}-\mathrm{Cu}+\mathrm{H}-\mathrm{Pb}+\mathrm{H}-\mathrm{Zn}$ \\
$\mathrm{pH}+\mathrm{TOC}+\mathrm{TN}+\mathrm{TP}+\mathrm{T}-\mathrm{As}+\mathrm{T}-\mathrm{Cd}+\mathrm{T}-\mathrm{Cr}+\mathrm{T}-\mathrm{Cu}+\mathrm{T}-\mathrm{Pb}+\mathrm{T}-\mathrm{Zn}+\mathrm{H}-\mathrm{As}+\mathrm{H}-\mathrm{Cr}+\mathrm{H}-\mathrm{Cu}+\mathrm{H}-\mathrm{Pb}$ \\
$\mathrm{pH}+\mathrm{TOC}+\mathrm{TN}+\mathrm{TP}+\mathrm{T}-\mathrm{As}+\mathrm{T}-\mathrm{Cd}+\mathrm{T}-\mathrm{Cr}+\mathrm{T}-\mathrm{Cu}+\mathrm{T}-\mathrm{Sb}+\mathrm{T}-\mathrm{Zn}+\mathrm{H}-\mathrm{As}+\mathrm{H}-\mathrm{Cr}+\mathrm{H}-\mathrm{Cu}+\mathrm{H}-\mathrm{Pb}+\mathrm{H}-\mathrm{Sb}$ \\
$\mathrm{pH}+\mathrm{TOC}+\mathrm{TN}+\mathrm{TP}+\mathrm{T}-\mathrm{As}+\mathrm{T}-\mathrm{Cd}+\mathrm{T}-\mathrm{Cr}+\mathrm{T}-\mathrm{Cu}+\mathrm{T}-\mathrm{Pb}+\mathrm{T}-\mathrm{Zn}+\mathrm{H}-\mathrm{As}+\mathrm{H}-\mathrm{Cr}+\mathrm{H}-\mathrm{Cu}+\mathrm{H}-\mathrm{Pb}+\mathrm{H}-\mathrm{Sb}+\mathrm{H}-\mathrm{Zn}$ \\
$\mathrm{pH}+\mathrm{TOC}+\mathrm{TN}+\mathrm{TP}+\mathrm{T}-\mathrm{As}+\mathrm{T}-\mathrm{Cd}+\mathrm{T}-\mathrm{Cr}+\mathrm{T}-\mathrm{Cu}+\mathrm{T}-\mathrm{Pb}+\mathrm{T}-\mathrm{Sb}+\mathrm{T}-\mathrm{Zn}+\mathrm{H}-\mathrm{As}+\mathrm{H}-\mathrm{Cu}+\mathrm{H}-\mathrm{Cr}+\mathrm{H}-\mathrm{Pb}+\mathrm{H}-\mathrm{Sb}+\mathrm{H}-\mathrm{Zn}$ \\
$\mathrm{pH}+\mathrm{TOC}+\mathrm{TN}+\mathrm{TP}+\mathrm{T}-\mathrm{As}+\mathrm{T}-\mathrm{Cd}+\mathrm{T}-\mathrm{Cr}+\mathrm{T}-\mathrm{Cu}+\mathrm{T}-\mathrm{Pb}+\mathrm{T}-\mathrm{Sb}+\mathrm{T}-\mathrm{Zn}+\mathrm{H}-\mathrm{As}+\mathrm{H}-\mathrm{Cd}+\mathrm{H}-\mathrm{Cr}+\mathrm{H}-\mathrm{Cu}+\mathrm{H}-\mathrm{Sb}+\mathrm{H}-\mathrm{Zn}+\mathrm{H}-\mathrm{Pb}$ & 0.921 \\
\hline
\end{tabular}




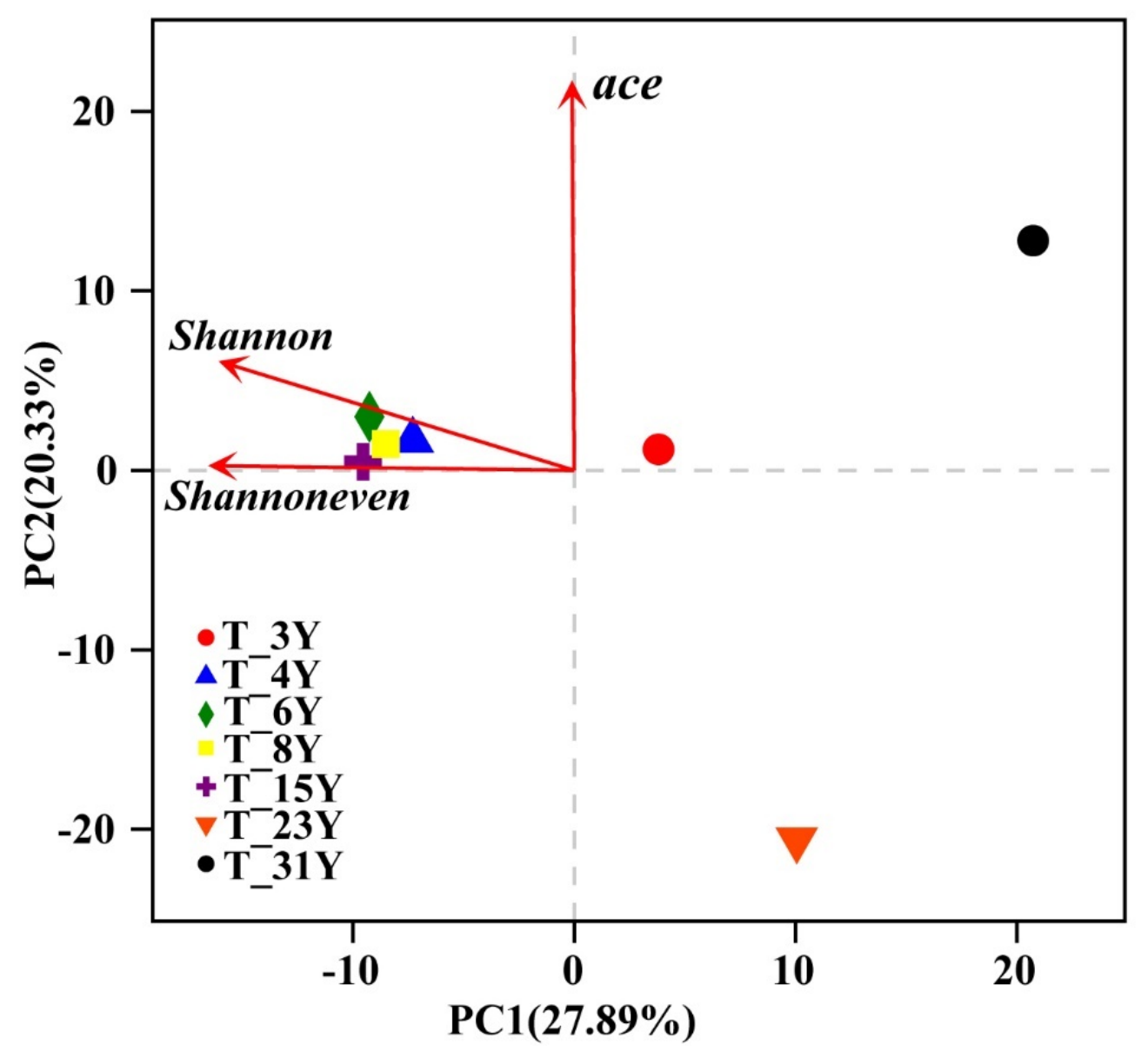

Figure S1. Principal component analysis based on relative genus abundance showing major differences in different seven tailings sites with different

abandoned times. 